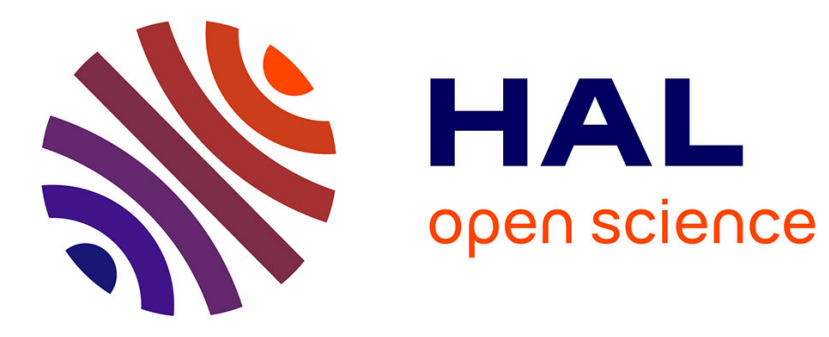

\title{
Late Quaternary co-seismic sedimentation in the Sea of Marmara's deep basins
}

\author{
Christian Beck, Bernard Mercier de Lépinay, Jean-Luc Schneider, Michel \\ Cremer, Namik Cagatay, Evrard Wendenbaum, Sébastien Boutareaud, \\ Guillemette Ménot, Sabine Schmidt, Olivier Weber, et al.
}

\section{To cite this version:}

Christian Beck, Bernard Mercier de Lépinay, Jean-Luc Schneider, Michel Cremer, Namik Cagatay, et al.. Late Quaternary co-seismic sedimentation in the Sea of Marmara's deep basins. Sedimentary Geology, 2007, 199, pp.69-85. 10.1016/j.sedgeo.2005.12.031 . insu-00178600

\section{HAL Id: insu-00178600 \\ https://hal-insu.archives-ouvertes.fr/insu-00178600}

Submitted on 11 Oct 2007

HAL is a multi-disciplinary open access archive for the deposit and dissemination of scientific research documents, whether they are published or not. The documents may come from teaching and research institutions in France or abroad, or from public or private research centers.
L'archive ouverte pluridisciplinaire HAL, est destinée au dépôt et à la diffusion de documents scientifiques de niveau recherche, publiés ou non, émanant des établissements d'enseignement et de recherche français ou étrangers, des laboratoires publics ou privés. 
Title:

\section{Possible Late Quaternary co-seismic sedimentation in the Sea of Marmara's deep basins}

Authors:

Christian Beck ${ }^{1}$, Bernard Mercier de Lépinay ${ }^{2}$, Jean-Luc Schneider ${ }^{3}$, Michel Cremer ${ }^{3}$, Namik Çağatay ${ }^{4}$, Evrard Wendenbaum ${ }^{1,2}$, Sébastien Boutareaud ${ }^{3,1}$, Guillemette Ménot-Combes ${ }^{5}$, Sabine Schmidt ${ }^{3}$, Olivier Weber ${ }^{3}$, Kadir Eris ${ }^{4}$, Rolando Armijo ${ }^{6}$, Bertrand Meyer ${ }^{6}$, Nicolas Pondard $^{6}$

and the MARMACORE cruise party: J.-L. Turon ${ }^{3}$, L. Labeyrie ${ }^{7}$, E. Cortijo ${ }^{7}$, Y. Gallet ${ }^{6}$, N. Gorur $^{8}$, A. Gervais ${ }^{3}$, M.-H. Castera ${ }^{3}$, L. Londeix ${ }^{3}$, A. de Rességuier ${ }^{3}$, A. Jaouen ${ }^{9}$.

\section{Adresses:}

(1) Laboratoire de Géodynamique des Chaînes Alpines, U.M.R. C.N.R.S. 5025, Université de Savoie, 73376 Le Bourget du Lac, France. E-mail : beck@univ-savoie.fr

(2) Géosciences Azur, U.M.R. C.N.R.S. 6526, Université de Nice-Sophia-Antipolis, 06560 Valbonne, France.

(3) Département de Géologie et Océanographie, U.M.R. C.N.R.S. 5805, Université de Bordeaux I, 33405 Talence Cedex, France.

(4) Geology \& Mining, Technical University of Istanbul.

(5) Lamont-Doherty Earth Observatory, Colombia University, New York.

(6) Institut de Physique du Globe de Paris, CNRS UMR 7578, Université Pierre et Marie Curie, 75252 Paris.

(7) Laboratoire des Sciences du Climat et de l'Environnement, U.M.R. C.N.R.S.-C.E.A. 1572,

91198 Gif-sur-Yvette, France.

(8) TUBITAK-MAN, PO Box 21, 41470 Gebze, Kocaeli, Turquey.

(9) IPEV, Technopole Brest-Iroise, BP 75, 29280 Plouzané, France.

\section{CONTENT:}

Key-words :

Abstract:

Introduction

I - Geodynamic and paleoenvironmental settings

II - The Late Pleistocene-Holocene sedimentary fill of the Sea of Marmara: overview of MARMACORE Cruise's results.

II-1- Technical aspects.

II-2 - Sediments composition and layering types.

II-3 - Chronology and correlation with data from shelves.

II-3-a-Carbone 14 data.

II-3-b-The lacustrine-to-marine transition.

II-4-Occurrence of a major pre-Late Glacial sedimentary "event" - megaturbidite, sismoturbidite - in the Central Basin.

II-4-a- Ocurrence of a pre-Late Glacial Homogenite.

II-4-b- Association of the pre-Late Glacial Homogenite with a coarse-sand and mudclasts layer.

II-4-c- Depositional model for the pre-Late Glacial Event and smaller-sized similar events. 
III - Dilatation of the sedimentary pile with increasing depth in the Central Basin

III-1- Correlation between Cores MD-2431 and MD-2429.

III-2- Strong lateral thickness increase in the marine sedimentary sequence.

III-3- Specific imprints of major earthquakes in the marine sedimentary sequence.

III-4- Time distribution of sedimentary "events" in Central Basin's sedimentary record.

Conclusions: major earthquake control on time and space distribution of the sediments in the Sea of Marmara deep basins.

Key-words :

Sea of Marmara, Late Quaternary, cores, high resolution seismic, earthquakes, turbidites, homogenites.

\section{Abstract:}

The deep, northern, part of the Sea of Marmara (northwestern Turkey) is composed of several aligned, actively subsiding, basins, which are the direct structural and morphological expression of the North Anatolian Fault's northern branch. The last $20 \mathrm{kyr}$ of their sedimentary fill (lacustrine before $12 \mathrm{kyr}$ BP) have been investigated through giant piston coring onboard R/V MARION-DUFRESNE (MARMACORE Cruise, 2001) and $3.5 \mathrm{kHz}$ seismic-reflection imagery; the latter was completed by profiles recorded onboard $\mathrm{R} / \mathrm{V}$ ATALANTE during MARMARASCARPS Cruise (2002). Especially during the lacustrine stage, the infilling of the deep basins (Tekirdağ, Central, Kumburgaz, and Çinarcic Basins; up to $1250 \mathrm{~m}$ depth) was dominated by turbidites (with coarse mixed siliciclastic and bioclastic basal part), intercalated in "hemipelagic-type" fine-grained calcareous and slightly siliceous clays. Often - especially in the thickest ones - the turbidites show strong segregation and sharp boundary between coarse part and suspended-load part. In the Central Basin, the $8 \mathrm{~m}$ of a unique sedimentary event include a 5 to $8 \mathrm{~m}$-thick "homogenite" well imaged on seismic profiles. The latter is interpreted as related to a major - here earthquake-triggered - tsunami effect, as described in Eastern Mediterranean by Kastens and Cita (1981). In the marine (Holocene) upper part of the sedimentary fill, repeated to-and-fro structures, affecting silt or fine sand, are evidencing seiche-like effects and, thus, earthquake triggering too. Detailed correlations between two deep coring sites (1250 and $1200 \mathrm{~m})$ indicate more than $100 \%$ overthickening in the deepest one; this implies specific processes of distribution of terrigenous input by dense hyperpycnal currents (high kinetic energy, seiche effect, complex reflections on steep slopes). The peculiar sedimentary infilling of the Sea of Marmara's 
Central Basin (and, by extrapolation, of the whole set) is tentatively interpreted as a direct consequence of the strong seismic activity; the imprint of the latter is more obvious prior to the base of the Holocene, as environmental conditions favoured marginal accumulation (especially on the southern shelf) of large amounts of erosion products available for mass wasting .

\section{Introduction}

Since the results of different investigations conducted on both marine and lacustrine fills, the direct or indirect sedimentary effects of strong earthquakes have been underlined and progessively taken in account as paleoseismic indicators (Kuenen, 1958; Sims, 1973, 1975; Ben Menahem, 1976; Field et al, 1982; Séguret et al, 1984; Seilacher, 1984; Doig, 1985, 1991; El Isa \& Mustafa, 1986; Anand \& Jain, 1987; Tuttle \& Seeber, 1991; Guiraud \& Plaziat 1993; Plaziat et al, 1988; Adams, 1990; Piper et al, 1992; Roep \& Everts, 1992; Marc \& Agnon, 1995; Moretti \& Tropeano, 1996; Beck et al, 1996; Alfaro et al, 1997; Pratt, 1998; Calvo et al, 1998; Chapron, 1999; Chapron et al, 1996, 1999; Lignier et al, 1998; etc.). These effects and their sedimentary record appeared particularly obvious in isolated marine basins and large lakes, submitted to significant seismo-tectonic activity (Hempton \& Dewey, 1983; Siegenthaler et al, 1987; Ringrose, 1989; Van Loon et al, 1995; Syvitski \& Schafer, 1996; Mörner, 1996; Chapron et al, 1999; Shiki et al, 2000; Gorsline et al, 2000; De Batist et al, 2002; Arnaud et al, 2002; Beck, 2005; etc.). During the last decade, these sedimentological investigations have been developed towards a more paleoseismological approach, through: 1) analogic modelling (Caselles et al, 1997; Moretti et al, 1999); 2) comparison of geotechnical and seismological parameters (Obermeier, 1989; Obermeier et al, 1989; Audemard \& De Santis, 1991; Vittori et al, 1991; Rodriguez-Pascua et al, 2002); 3) tentative delimitation of a "paleo-epicentral" area based on a set of synchronous lacustrine records, and use of different kinds of archives for the same event (Allen, 1986; Lignier, 2001; Becker et al, 2002, 2004; Carrillo et al, 2005).

In the Mediterranean realm, a major volcanic and seismic event and its consequences (tsunami) have been considered as generating huge sedimentary reworking (Kastens \& Cita; 1981; Cita et al, 1996; Cita \& Rimoldi, 1997). The resulting deposit appears to specifically fill the deepest parts and to smoothen previous relieves in deep central-eastern Mediterranean basins; on high resolution seismic reflection profiles, it corresponds to a particular transparent layer called "homogenite" (Kastens \& Cita, 1981) or "unifite" (Stanley, 1981). Based on 
these previous concepts and other investigation results on large intra-mountainous lakes, the deepest part of the Sea of Marmara - which underwent a lacustrine episode prior to the last eustatic rise - was investigated as a possible recorder of the strong and frequent earthquakes occurring along the North-Anatolian Fault (Mercier de Lépinay et al, 2003; Beck et al, 2003).

\section{I - Geodynamic and paleoenvironmental settings}

As evidenced by seismo-tectonic surface studies, seismological investigations, radar interferometry and GPS geodetic comparisons, the North-Anatolian Fault is considered as a major active boundary between Aegean-Anatolia and Eurasia plates (Ambraseys, 2002; Ambraseys \& Finkel, 1991; Armijo et al , 1999; 2002; Le Pichon et al, 2001; Rangin et al, 2001; McClusky et al, 2002; etc.)( Fig. 1; a and c: present day kinematics based on GPS surveys; $a$ and b: general recent tectonic framework indicating extensional, strike slip, and convergence structures). In northwestern Turkey, the northern branch of this right-lateral strike slip fault system - with a set of recent high-magnitude earthquakes (Barka, 1996; Stein et al, 1997; Hubert-Ferrarri et al, 2000; etc.) - is crossing the Sea of Marmara and more precisely its deep northern part. Previous seismic reflection surveys have underlined the general geometry of the Cenozoic deep sedimentary fill and its direct relationships with active faulting (Le Pichon et al, 2001; Ǐmren et al, 2001; Demirbağ et al, 2003; etc.). The present day tectonic framework is considered as initiated during the Late Miocene (Wong et al, 1995; Ǐmren et al, 2001); it involves ophiolitic assemblages, metamorphic and igneous rocks (intrusions and subaerial volcanics), from Paleozoic to Tertiary in age. They represent part of the Pontides (North) and the Taurides (South) peri-Mediterranean belts. The main relieves (metamorphic and igneous units), representing potential terrigenous sources, are located on the southern side of the Sea of Marmara, while the northern border has smaller elevation (Tertiary sediments and volcanics); this situation is responsible for the terrigenous input on the southern shelf (Ergin et al, 1991, 1999). The drainage pattern issued from the southern main relieves converges towards tributaries of the Sea of Marmara, while, north of it, the main hydrologic system flows westwards, avoiding significant input on the northern shelf.

As connecting the eastern Mediterranean (Aegean Sea) and the Black Sea through two shallow sills (Dardanels and Bosphorus) the Sea of Marmara underwent the consequences of the last glacio-eustatic cycle (Ryan et al, 1997; Aksu et al, 1999; Çağatay et al, 2000, 2003; Major et al, 2002; etc) and recorded the associated $120 \mathrm{~m}$ sea-level rise. Recent paleoenvironmental studies through coring and seismic imagery have been dedicated, by 
different teams, to the analysis of the Black Sea/Sea of Marmara connexions and especially the last one considered as a major (catastrophic?) environmental change (Ryan et al, 1997; etc.). These recent modifications have been investigated through short gravity cores either in deep basins or in shallow shelves positions (Çağatay et al, 2000, 2003). The lacustrine to marine change is considered to have occurred around $12 \mathrm{kyr}$ BP Cal., and is represented either by a sharp limit in shallow marginal sites, and/or by a more progressive change in deep situations.

Although also concerned by these paleoenvironmental aspects, the here-presented part of MARMACORE Cruise's results mainly focuses on the search of impacts of the seismic activity on recent sedimentary processes.

\section{II - The Late Pleistocene-Holocene sedimentary fill of the Sea of Marmara: overview of MARMACORE Cruise's results.}

\section{II-1- Technical aspects.}

The MARMACORE Cruise took place from the $20^{\text {th }}$ of August and the $13^{\text {th }}$ of September 2001, as part of the larger GEOSCIENCES MD 123 program. Onboard R/V MARION-DUFRESNE, a set of 8 long piston cores were retrieved using the CALYPSO giant piston corer. Five cores were taken in deep situation (1250 to $1100 \mathrm{~m}$ ), and three in shallower parts (800 to $400 \mathrm{~m}$ ); $3.5 \mathrm{kHz}$ profiles were performed for site-surveying and for longer profiles across the different basins (Fig. 2) during transits. The MARAMACORE cruise's seismic grid was later completed by $3.5 \mathrm{kHz}$ profiles acquired during MARMARASCARPS cruise, in addition to short piston cores (see Armijo et al, 2004); the whole grid is represented on Fig. 2. The eight long cores (21,8 to $37,3 \mathrm{~m}$; labelled MD01-2424 to MD01-2432) were divided in 1,5 m long sections; non destructive measurements profiles (magnetic susceptibility, sonic velocity, gamma-ray densimetry) were performed using I.P.E.V.'s GEOTEK multitools core logger. Core sections were then split for visual description (layering type, sedimentary and tectonic structures) and preliminary sampling (smear slides for terrigenous and biogenic contents analysis, plant debris and wood fragments for 14C dating). Specific attention was paid to coarse terrigenous layers, microtectonic structures, and possible liquefaction features.

Preliminary shipboard studies were completed onshore by detailed Magnetic Susceptibility profiles using a BARTINGTON MS2 contact sensor (with $5 \mathrm{~mm}$ intervals). 
Laser microgranulometric measurements were performed using a MALVERN Mastersizer $\mathrm{S}$ equipment. X-ray pictures of split cores (MD01-2429 and MD01-2431) have been realized with D.G.O.'s SCOPIX system (University of Bordeaux I); X-ray scanner tomography (in I.F.P. laboratory) have been performed on a selected portion of microfractured sediments in core MD01-2431.

\section{II-2 - Sediments composition and layering types.}

All analyzed sections (230 $\mathrm{m}$ cumulated) are basically made of fine-grained terrigenous material with interlayered, sharply different, sequences that will be detailed here-after. The upper, marine, parts of the eight cores (see Fig. 3), are almost entirely made of faintly layered clayey-silty, slightly calcareous, mud. Mean grain size, median, and mode, range between 4 and $8 \mu \mathrm{m}$, while calcite content is rather constant, around 15 $\%$; within the latter, detrital carbonate grains are generally dominant with respect to bioinduced or biogenic components. This fine-grained - "background" - sediments are locally enriched in freshwater Diatoms frustules in the lower part; in the upper part, dispersed calcareous nannoplancton is present. In core MD01-2425 and MD012427, we observed a conspicuous millimetric layer consisting of an almost holopelagic nannoplancton ooze (Fig. 3); we tentatively used this "bloom" as a correlation chronological marker. The silty terrigenous fraction is siliciclastic, mainly from volcanogenic origin (fresh plagioclase, amphibole and pyroxene, fresh automorphous brown mica, opaques minerals); metamorphic and plutonic rocks-derived components are minor (white micas, amphiboles, deformed quartz, etc.). More frequently in the lower part, diffuse, or concentrated in association with bioturbation, dark pigmentation is developed, due to diagenetic sulfides.

Particular individual layers ("events") or successions of layers are intercalated within these "background" clayey-silty (marine or lacustrine) sediment:

ash layers: two major probable pyroclastic fallout events (up to $8 \mathrm{~cm}$ thick) have been found in Cores MD01-2428 and MD01-2430 and tentatively correlated (afl1 and afl-2; Fig. 3) between these two sites which show a much lower sedimentation rate; several discrete (less than $5 \mathrm{~mm}$ thick) ash-enriched layers are present in all cores;

- $\quad$ silty-sandy laminated intervals; they are abundant in median parts (lower half of the marine interval) of Cores MD01-2424, MD01-2425, MD01-2427 (eastern 
basins), and more dispersed (several tens of $\mathrm{cm}$ "sequences") in Core MD012432 (western basin). In Cores MD01-2429 and MD01-2431 (Central Basin), they are spaced thin intervals within the upper marine sequence (detailed discussion in III-2). They consist of millimetric (to infra-millimetric) parallel planar bedding, involving subtle changes in grain-size (silt, fine sand) and clastic components. According to textures and components, we interpret this layering as related to bed-load transport and settling (and not to fluctuations in planctonic production and/or in parapelagic suspended load), thus implying seafloor horizontal distribution. The apparent cyclic layering could represent (seasonal?) variations in locally developed bottom currents as responses to surface ones (in a convective-like system), more active close to the two sills and during the beginning of the marine-connected sedimentation (?). An alternate explanation could be that they represent distal distribution of flood-induced dense bottom currents, and thus periods of particularly strong and repeated runoff (?). These speculative interpretations need further detailed laboratory analysis (mineralogy, texture, time series, morpho-bathymetrical position, etc.);

- $\quad$ turbiditic (in the broadest sense) sequences; they are common in the deepest cores (MD01-2424, MD01-2425, MD01-2427, MD01-2429, MD01-2431) excepted for the Tekirdag Basin. With centimetric to decimetric thicknesses, they are almost entirely intercalated within the lower (lacustrine) part of the analyzed successions, the highest (visually estimated) frequency being found in Central Basin's Core MD01-2431. They usually display a sharp erosive base, sometimes with ball-and-pillow structures; the basal coarse sands contain shell fragments concentrations, and sometimes vegetal debris; mineralogy of the (dominant) siliclastic fraction is similar to the one observed in finer-grained strata (see above). Part of these turbidites show a classical progressive fining upward, while for the thickest ones, an abrupt contact separates the bedload basal term from the suspended-load upper term, the latter turning into a "homogenite"type layer; one of the following paragraphs will focus on these specific sedimentary "events", and especially on one 8-to-12 m thick unique gravityemplaced layer, including a 5-to-8 $\mathrm{m}$ thick homogenite.

\section{II-3 - Chronology and correlation with data from shelves.}


Shipboard preliminary lithostratigraphical correlations (Mercier de Lépinay, Labeyrie, Çağatay, et al, 2001) was proposed based on a few conspicuous layers (major tephra and nannoplankton "blooms"). More detailed observations (biogenic content) allowed decipher the marine upper part from the lacustrine lower sediments, thus completing the correlation chart.

II-3-a-Carbone 14 data. A.M.S. C14 analysis were performed on 10 wood fragments found during shipboard core-splitting (plotted on Fig. 3 logs), in Lamont-Doherty Earth Observatory (9 samples) and in Zürich Federal Polytechnical Institute (1 sample). The results were calibrated according to Stuiver et al (1998), and using OxCal software; the values plotted on Fig. 3 logs correspond to highest confidence intervals. Most of the cores appear to represent the Holocene and part of the Late Pleistocene; the longest core (MD01-2429, 37,3 m) - retrieved from the deepest sub-basin of the Central Basin - appears to represent the shortest sampled time interval. At the opposite, cores MD01-2428 and MD01-2430 may represent the last 40000 to $50000 \mathrm{yrs} \mathrm{BP}$, if extrapolating mean sedimentation rates.

II-3-b-The lacustrine-to-marine transition. Our chronological data are in agreement with the hypothesis of a lacustrine-to-marine transition occurring around $12 \mathrm{kyr} \mathrm{BP}$ cal. as proposed by different authors (Çağatay et al, 2000, 2003; Tolun et al, 2002; etc.). Due to the importance of the "corridor" situation of the Sea of Marmara, between the Black Sea and the Aegean, the late Quaternary connexion has been investigated and discussed by different authors, based on coring results and high resolution seismic reflection data, (Aksu et al, 2002a and b; Major et al, 2002; Hiscott \& Aksu, 2002; etc.). Our preliminary results are in agreement with chronological data from shallow sedimentary records (southern shelf and Izmit Gulf) (Çağatay et al, 2000, 2003); we did not observed any abrupt change, favouring the "deep sill" rather than the "shallow sill" models of Major et al (2002).

Using detailed layering and sediment textures contrasts in Cores MD01-2429 and MD01-2431, two synthetic logs were built, with potentially reflecting interfaces, and then compared with corresponding portions of $3.5 \mathrm{kHz}$ seismic lines (taking in account an estimation of theoretical vertical resolution) (Fig. 4). In the upper (marine) part, the "permanent" sedimentation is slightly variable with a high siliclastic (clay-silt) and calcareous fraction, and is interrupted by only a few coarse turbiditic layers. The last-mentioned are correlated with a few high amplitude reflectors (see Fig. 4-A, 0-32 m interval of Core MD012429 and corresponding acoustic image; 1640-1685 ms t.w.t.); other reflections have variable amplitude and variable frequency. At the difference, in the lower (lacustrine) part the "permanent" sedimentation is finer-grained and with a more constant composition (dominant 
biogenic and bio-induced material). This sediment is mentioned as "hemipelagic-type" and often appears as clear thin intervals (few $\mathrm{cm}$ to ten $\mathrm{cm}$; close ups of Fig. 5) between numerous interlayered coarse turbiditic layer; added to the contrast with a more constant background sediment, they are producing reflections with rather constant amplitude and high frequency (see Fig. 4-A, interval below $32 \mathrm{~m}$ of Core MD01-2429 and corresponding acoustic image below 1685 ms t.w.t.). Thus, the separation between the upper marine period of sedimentation and lower lacustrine ("hemipelagic-type") can also be done on the high resolution seismic imagery, and, at least for the two studied sites, its is coherent with other previously mentioned data. On Core MD01-2431 (Fig. 4-B), the characterization of the lower, "hemipelagic-type", interval is not so obvious due to the interlayering of the $8 \mathrm{~m}$-thick megaturbidite described in the next paragraph.

\section{II-4 - Occurrence of a major pre-Late Glacial sedimentary "event" - megaturbidite, sismoturbidite - in the Central Basin.}

The different seismic profiles crossing the Central Basin (Fig. 2) evidenced a conspicuous acoustically transparent layer (up to $8 \mathrm{~ms}$ two-ways-time thick). Although the analysis of the complete grid did not permit, with respect to the theoretical vertical resolution, to clearly identify this layer in other sub-basins (Tekirdağ, Kumburgaz, Çinarcic), the chronostratigraphic precision of different deep cores from the last-mentioned did not rule out the existence of a more discrete signature (similar to re-depositional events illustrated on Fig. 5) of the same sedimentary "event". The homogenous layer, named "homogenite" with reference to the concept of Kastens and Cita (1982), appears to be the third (upper) term of a unique megaturbidite; the "homogenite" will be described prior to discussing the genesis of the whole event.

\section{II-4-a- Ocurrence of a pre-Late Glacial Homogenite.}

The profiles presented on Fig. 7 (located on Fig. 6) underlined a specific distribution of the homogenous transparent acoustic layer:

- restriction to the very deepest parts of the Central Basin (below $1190 \mathrm{~m}$ depth),

- sharp lateral ending (see line cb 14, Fig. 7),

- increasing thickness with increasing depth (comparison of central and western part of line cb3, Fig. 7). Although the "homogenite" represents very fine-grained material (lacking 
vertical changes), the non-draped configuration implies a deep horizontal arrival, similar to any hyperpycnal depositional process. Based on the whole $3,5 \mathrm{kHz}$ grid of the Central Basin, the total volume is estimated between 0,6 and $1,4 \mathrm{~km}^{3}$.

Core MD01-2431 completely crossed this homogenous layer; it can be viewed on a general reconstructed picture of the core (Fig. 8). Within the uppermost $70 \mathrm{~cm}$, three dispersed wood fragments could be extracted and dated by Accelerator Mass Spectrometry C14 measurement. Calibrated (with maximum confidence) ages intervals are: 16,6-17,3 kyr BP twice (samples A1 and A2), 15,5-16,0 kyr BP (sample A3). Considering the wood debris as reworked, we propose to select the youngest age as the closest to the homogenite deposition age, if admitting a unique event (see arguments below). About two meters higher in a layered part of Core MD01-2431, another wood fragment yielded a 14,1-14,8 kyr BP (sample A4), which is in agreement with the age proposed for the homogenite, and with the lacustrine-to-marine transition detected above. In the following, we will name this unit the pre-Late Glacial Homogenite (PLGH).

\section{II-4-b- Association of the pre-Late Glacial Homogenite with a coarse-sand and mudclasts layer.}

Between the PLGH and the next underlying "background" hemipelagic-type layer, two thick and coarse layers are intercalated (Fig. 8):

- dark silicilastic (non stratified) coarse sand (1,7 m thickness), with minor biogenic content (highly fragmented Molluscs shells, from shallow coastal environment), and dispersed millimetric wood debris;

- $\quad$ mud clasts breccia (1,0 m thickness); centimetric clasts are made of fine-grained grey to whitish sediment, with locally preserved stratification; they are embedded within a coarse sand matrix identical to the overlying one. Based on microscopic observation (terrigenous and biogenic fractions), the mud clasts are considered as reworked from the lacustrine well stratified underlying sequence.

The Magnetic Susceptibility signature of these two coarse layers (Fig. 9, left graph) reinforces the particularity of the coarse sand and the similarity between the mud clasts and the underlying succession. The M.S. also shows a highly constant value for the homogenite; the upper marine sequence also yielded (between $2 \mathrm{~m}$ and $6 \mathrm{~m}$ ) a rather constant M.S. profile but with a different (higher) mean value. The homogenite carbonate content is nearly constant, between 12,9 à $13,1 \%$. 
Detailed grain-size vertical evolution profiles was built with regular sampling in homogenite and coarse sand layers, evidencing highly constant parameters (mean grain size, mode, median; between 6 and $7 \mu \mathrm{m}$ ) in the homogenite, and less constant ones in the coarse sand. A part of the results are plotted as a skewness vs. sorting diagram (Fig. 10), evidencing or confirming:

- $\quad$ fluctuations of depositional dynamics in the bed-load part (their frequency may be higher than what the sampling interval allowed to detect);

- $\quad$ sharp transition between the coarse sand and the homogenite;

- $\quad$ highly constant distribution along the 5 meters of suspended-load upper part.

The three intervals are considered as parts of a unique re-depositional "event", totalizing 8 meters thickness in Core MD01-2431, named in the following the pre-Late Glacial Event (PLGE).

Fig. 11 close ups illustrate different part of the PLGE: the top, with transition from homogenite to hemipelagic-type sediment (11-d), the limit coarse sand/homogenite (11-e), the limit mud clasts interval/coarse sand (11-f), the base of the mud clasts interval (11-g). Excepted for the last-mentioned, the whole set is composed of allochtonous siliclastic components derived from previously deposited shallower (shelf and shelf margin) sediments. The Diatoms assemblages determined within the sand, the mud-clasts breccia, and the homogenite (Boutareaud, 2003) belong to different mixed shelf and delta environments; this confirms the reworked origin and especially argues against a unique "hemipelagic" source for the homogenous upper term.

\section{II-4-c- Depositional model for the pre-Late Glacial Event and smaller-sized similar events.}

Generally speaking, the depositional model that can be proposed for the PLGE, follows the concept of megaturbidite: large size mass wasting turning into dense hyperpycnal flow (Bowen et al, 1984; Mulder \& Cochonat, 1996; Mulder et al, 1994; Bouma, 2000; etc.). Nevertheless, the sharp limit between the coarse sand and the upper fine-grained unit and the lack of clear internal structures differ from the usual configuration of classical turbiditic sequences. This sharp limit is also frequent on smaller-size sedimentary "events" (Fig. 5). The Mediterranean "Minoan" homogenite (Kastens \&Cita, 1982; Cita et al, 1996) is not associated to a coarse base layer, and this type of unit have been called "unifites" (Stanley, 1981; Stanley \& Maldonaldo, 1981). The "hemiturbidite" concept has been proposed by Stow 
and Wetzel (1990) also for fine-grained homogenous layers, explained by a deep-seated separation of an upper fine-grained "cloud" from a lower coarser-grained layer, the former following a much longer trajectory. This separation may also be explained by a "hydraulic jump" (Fig. 13, case A). This concept explains the horizontal separation, within a unique mixed particulate flow, of an upper suspended-load flood from a (coarse-grained) basal, quickly immobilized, layer, because of a bottom relief acting as an obstacle. Initially proposed for coastal sediments it has been applied to deeper situation as deltaic foresets and turbidites (Komar, 1971; Nemec, 1990; Kubo \& Yokokawa, 2001; Allen, 2001) not necessarily implying an obstacle. Concerning a turbiditic current, the separation ("jump") may occur while crossing the slope (within the canyon), or at the deep plain/slope break (Fig. 13, case B).

Nevertheless, for the PLGE and for smaller-sized similar sedimentary "events" (Fig. 5), the coarse basal layers are present and supposed to have spread horizontally together with the upper fine-grained suspension; furthermore, the $3,5 \mathrm{kHz}$ profiles show the same "acoustic" structure (and thus same constitution) for the PLGE in the whole Central Basin; the $3,5 \mathrm{kHz}$ profiles do not evidence any major relief below the PLGE, which underlying surface was flat before subsequent faulting. The alternate explanation we propose is a long-lasting bottom current with several superimposed direction changes, leading into an almost complete segregation of the bed-load from the suspended-load (Fig. 11). This could be induced by: 1) either a high velocity turbidity current (high kinetic energy) undergoing several reflections against the steep slopes of the Central Basin with progressive damping (following the concept of "contained turbidites" of Pickering \& Hiscott, 1985)(Fig. 13, case C); 2) or an oscillatory movement of the whole water mass, initiated by a sudden bottom modification (co-seismic displacement, or huge sub-aqueous slump)(Fig. 13, case D). This tsunami effect has been analyzed and modelled for the Sea of Marmara (Yalçiner et al, 2002); it also can be considered as a seiche effect as known in large lakes (Siegenthaler et al, 1987; Chapron et al, 1999). The second hypothesis is directly "paleoseismic", and the first emphasized mechanism is also often considered as earthquake-triggered ( $c f$. Nakajima \& Kanai, 2000). We considered (see also Chapron et al, 1999; Beck, 2005) that the specific oscillatory mechanism is responsible for:

- additional extraction of clayey-silty matrix from the initial flux, leading to an increased volume of upper suspended load, and sharpening the boundary between coarse and finegrained layers; 
- concentration ("ponding") of the homogenite deposit within deepest hollows. At the opposite, in a single fine-grained turbiditic flooding on a wide basin floor, the widespread and thick upper suspended "cloud" may partly lead to upslope deposition with local draped configuration (Dolan et al, 1989).

As we do not have any direct evidence (on HR seismic images) for corresponding slump scars, the hypothesis of the gathering of several coeval turbidites (channelized by the different canyons of the southern edge of Central Basin, Fig. 6) into a unique bottom flux, cannot be ruled out. Two departure areas could be proposed: the edge of the main large shallow southern shelf or the deeper irregular inclined shelf mainly bounding the eastern half of the Sea of Marmara (North of Imrali Island, see on Fig. 2 or Fig. 6). We favour the first hypothesis because of two different facts: 1) following the present day bathymetry, the Central Basin is not directly concerned by the drainage crossing the deep eastern shelf; 2) because of a slighter dipping slope, the latter was well imaged by HR seismic and no slump scar were detected.

Taking in account the different available data previously mentioned, we favour, for this huge pre-Late Glacial Event, the combination of a major earthquake (16000 yrs BP) occurring during a period of high terrigenous sedimentary supply in relation with specific Late Glacial climatic conditions. With respect to smaller-sized reworking events (Fig. 5), they are believed to represent similar mechanisms, with similar triggering, and in a similar situation with respect to climatic fluctuations. In several cases, these turbiditic layers appear "sealing" previous disturbances of underlying sediment/water interface (Fig. 11, close up b); thus three types of impact of major earthquake may be very schematically proposed (schematized on Fig. 12). The volume differences (or thickness differences) between all these sedimentary events, must be related to a combination of: i) the characteristics of the triggering shaking (unique short event vs. repeated shocks); ii) the type of impact on sedimentation (number of induced mass wasting, size of slope failure, intensity of direct bottom disturbance (Rodriguez-Pascua et al, 2002)), iii) the distance between investigated depositional basin and epicentral area.

All these sedimentary "events" have been investigated in the lacustrine lower part of the Central Basin's recent fill as they are striking features; does it means that this process decreased or disappeared in the Holocene? Or did the earthquakes sedimentary recording became weak or absent? The following paragraph is dealing with the impact of strong seismic activity during the marine (Holocene) sedimentation. 


\section{III - Dilatation of the sedimentary pile with increasing depth in the Central Basin}

The general Cenozoic configuration of the Sea of Marmara's sedimentary fill, as imaged by seismic reflection ( Rangin et al, 20001; Le Pichon et al, 2001 ; Ǐmren et al, 2001), clearly indicated a complete, long term, tectonic control of the sedimentary fills, especially for internal configurations in the different sub-basins. With the higher resolution here used, this relationship may be envisaged, not as a continuous double process (with mean values of sedimentation rates and fault displacements), but rather as the succession of incremental events (with instantaneous sedimentation rates and co-seismic faults scarps). Both on $3.5 \mathrm{kHz}$ profiles and on cores, this second investigation scale allows to explain very local and high thickness increases as the one evidenced in the Central Basin deepest part (Fig. 7).

\section{III-1- Correlation between Cores MD-2431 and MD-2429.}

The synthetic seismic logs (Fig. 4) based on core lithological content, and constructed for general seismostratigraphy, were then used for detailed correlation across the deep fresh scarps zone subdividing the Central Basin bottom. The correlation between Cores MD012429 and MD01-2431 (Fig. 14), established with 3,5 kHz image completed by lithogical comparisons, illustrates this difference. The horizontal distance is less than $10 \mathrm{~km}$ and the bottom depths are respectively about $1250 \mathrm{~m}$ and $1200 \mathrm{~m}$. If assuming a constant mean sonic velocity in the imaged sedimentary pile, the upper marine part (above the "hemipelagite-type" occurrences) is three times thicker than its lateral time equivalent; the same increased rate may be measured for the lacustrine part overlying the PLGE. The "homogenite" part of the last mentioned shows a $75 \%$ thickness increase. If considering the detailed accumulation processes in the lacustrine part (close ups of Fig. 5), the slow "background" sedimentation represents 10 to $20 \%$ of the total rate in Core MD01-2431 (higher situation, left log on Fig. 5). If considering Core MD01-2429 (lower situation, right log on Fig. 5) the sedimentary "events" - representing instantaneous deposits - appear (as the PLGE) strongly dilated, and, there, the "background" sedimentation represents less than $10 \%$ of the total rate. The "hemipelagic-type" thickness is almost similar in both cores (indicating absent or negligible reworking of this material), if considering either separate layers or their total amount. The strong total thickness increase in the lacustrine part, between the two sides, is thus basically due to the addition of the thickness differences of each individual gravity "events". According to the sedimentological interpretation proposed before (II-4-c), the difference between both 
sides of the scarp represents the recording of the successive major earthquakes affecting the Central Basin and/or its edges. As in the marine upper part such amount of sedimentary "events" were not observed in Cores MD01-2429 and MD01-2431, it arises the question of the processes leading to a similar strong thickness difference.

\section{III-2- Strong lateral thickness increase in the marine sedimentary sequence.}

As previously mentioned (II-2), the upper part of the studied sedimentary pile, corresponding to marine sedimentation (-12000 yr to Present), appears poorly layered and more homogenous, with very few striking coarse turbidites. The last mentioned may not account for the strong thickness increase measured between sites MD01-2431 and MD012429 (Fig. 14; location on Fig. 6). Then, several questions arise:

- what is(are) the exact depositional process(es) responsible for the general thickness increase on the deeper side of the main median scarp of the Central Basin?

- do the silty laminated episodes (Fig. 15 close ups) represent particular high terrigenous supply? Do they play the same role as the one attributed to the turbidites/homogenites for the lacustrine sequence (instantaneous huge supply)?

Two sets of data may argue for an explanation: the sediment composition (II-2), and the detailed layering as imaged by X-ray. The latter was performed using SCOPIX device; for each core section, a continuous X-radiography is done on a $1 \mathrm{~cm}$-thick longitudinal sediment slice (see close ups on Fig. 15).

The grain-size and the mineralogical content of the marine upper sequence indicate a quite continuous supply of silt (and locally fine sand), either as terrigenous suspended-load or, more likely, as slow bed-load bottom transport. This sedimentary process must account at least for part of the increased thickness in deepest situation, in a way similar to contouritic behaviour (local bottom current acceleration and subsequent higher particulate transport). A corollary is the question of the relative importance of in situ reworking and additional supply; the latter is more in agreement with the sedimentation rate and the grain-size.

Another question is the apparent episodic occurrence of these more silty laminated levels (examples of close ups $\mathbf{a}, \mathbf{b}$, and $\mathbf{e}$ on Fig.15); they may represent particular climatic episodes with strong run off and connected hyperpycnal distribution. Nevertheless, these laminated levels often overly apparently liquefied fine-grained layers (close ups $\mathbf{a}, \mathbf{b}, \mathbf{c}$, and $\mathbf{e}$, on Fig. 15); thus, two hypothesis may be proposed: i) these levels have a texture favourable to 
earthquake disturbances; ii) they represent themselves specific supply induced by major earthquakes. Several features reinforce the first hypothesis (Fig.15):

- low angle symmetric cross beddings (similar to coastal tidal "flaser" bedding) are intercalated within the laminated coarser episodes ("fb" on close ups a and $\mathbf{g}$ ); we interpret these features as induced by to-and-fro bottom displacements, and, thus, by seiche effects (earthquake consequence); a "contained turbidite" process cannot be envisaged here;

- intercalated ball-and-pillow structures (close up c), also favoured by textural contrasts between superimposed layers during shaking (Moretti et al, 1999);

- occurrence of water-escape veins starting from these laminated coarser episode, with probable associated "boudinage" (close ups $\mathbf{d}$ and $\mathbf{f}$ ).

In brief, during the (Holocene) marine sequence, the sedimentation appears mainly controlled by episodes of rather cyclic permanent bottom currents with variable suspendedload or bed-load, depending on velocity and available silty-sandy terrigenous feeding. The strong lateral thickness variation on both sides of the central scarp develops both in a continuous way with reinforcement by mean of separated depositional "events".

\section{III-3- Specific imprints of major earthquakes in the marine sedimentary} sequence.

For the lower (pre-Holocene) lacustrine sequence (II-4-c), we assumed that the different gravity reworking events (particularly the homogenites) were triggered by major earthquakes during a period of high terrigenous accumulation on the edges of the Sea of Marmara; microfracturation (brittle behaviour of unconsolidated sediment with high water content) is also believed to represent shaking imprint. If admitting a similar seismo-tectonic activity during the marine episode, we should search for other types of imprint of major earthquakes, as the accumulation process is different.

Among the possible earthquake-related features (Fig. 15) we observed:

- subvertical water-escape "vein structures" (close up d); the last mentioned have been described in soft sediments submitted to frequent tectonic and seismo-tectonic activity, as accretionnary complexes (Cowan, 1982; Ogawa \& Mitata, 1985; Brown \& Berhmann, 1990); - symmetrical flaser bedding-like structures indicating to-and-fro current (close up a) and, thus, seiche effects;

- boudinage of laminated layers (close ups $\mathbf{d}$ and $\mathbf{f}$ ) that we tentatively interpret as lateral spread effect; some dewatering veins are connected to theses stretched layers; 
- horizontal rupturing and displacement of vertical veins (close up a); we consider these structures as lateral spread shear, thus also related to seismic shocks; such structures have already been interpreted as earthquake imprints in old sedimentary formations (Föhlisch \& Voigt, 2001);

- liquefaction features (Fig. 15 close up a);

- often an association of these different types.

\section{III-4- Time distribution of sedimentary “events" in Central Basin's sedimentary} record.

Gathering visual observations and X-ray pictures of Cores MD01-2431 and MD012429, a preliminary rough estimation of time recurrence intervals of sedimentary "events" considered as earthquake-triggered is proposed. For the lacustrine part, Core MD01-2431 may be divided into a constant "hemipelagic"-type accumulation with a (slow) mean sedimentation rate and intercalated turbidites-homogenites (Fig. 5 close ups), as previously done in deep marine sedimentation by Adams (1990). Between the top of the PLHG and the base of marine sedimentation (16 kyr to $12 \mathrm{kyr} \mathrm{BP}$ ), the total mean sedimentation rate is about $1,5 \mathrm{~mm} / \mathrm{yr}$, implying a 0,15 to $0,30 \mathrm{~mm} / \mathrm{yr}$ rate for the "hemipelagic"-type sedimentation. Considering this component of the sediment as a planktonic bio-induced and bio-produced settling, then the same rate can be attributed to the "hemipelagic"-type interval of Core MD01-2429. In both cores (Fig. 5), these intervals are generally few $\mathrm{cm}$ thick; for $2 \mathrm{~cm}$, it should correspond to 35 to 60 years. About 45 major "events" are visible in Core MD01-2431 for a $6 \mathrm{~m}$ succession lasting about $4 \mathrm{kyr}$, leading to a mean 80 yrs recurrence time interval.

For the marine part, 6 major events ( $c f$. Fig. 15 close up a) could be correlated between the two cores; adding other types of disturbances and/or particular layering, 26 events occurred during the last $12 \mathrm{kyr}$ leading to a $480 \mathrm{yr}$ mean recurrence interval. The difference observed in apparent "frequencies" between marine and lacustrine sequences could be explained as follow:

- only major local earthquakes (directly affecting the Central Basin substratum and its edges) are recorded within the marine part;

- an easier triggering of subaequous slumps related to more available sediments during Late Glacial (see II-4-c) may explain the higher "frequency" in the lacustrine sequence; furthermore the arrival of hyperpycnal flows on the Central Basin deep floor represent a larger provenance area (see submarine canyons pattern on Fig.6); 
- the estimated "frequency" for the lacustrine sequence is erroneously too high as part of the normal turbidites may be flood turbidites (Lignier, 2001; Arnaud et al, 2002; Beck, 2005) and thus related to climatic "events".

However, the mean estimated time recurrence interval appears of the same order as the measured recent distribution of major earthquakes along the northern branch of the N.A.F. (Ambraseys \& Finkel, 1991; Barka, 1996; Ambraseys, 2002; Armijo et al, 1999; 2002; Stein et al, 1997; Hubert-Ferrarri et al, 2000; etc); further more detailed analysis of sedimentary events in the different basins of the Sea of Marmara (and not only in the Central Basin) should precise these comparison both for the time and for the horizontal distributions of the sedimentary "events".

\section{Conclusions: major earthquake control on time and space distribution of the sediments in the Sea of Marmara deep basins.}

Although mainly based on a more detailed study of the Central Basin, the following conclusions may be extrapolated to the whole deep part of the Sea of Marmara, as indicated by similar sedimentary piles in all deep cores and same high resolution seismostratigraphic succession. The general shape of the recent fill and its internal configuration both evidence a clear control by seismic activity of the deep sedimentary fill.

Regarding the lower lacustrine sequence (approximately from $20000 \mathrm{yr}$ B.P. and 12000 yr B.P.), at least $90 \%$ of the infilling has to be considered as a non linear (incremental) process; the maximum instantaneous increment being the Pre Late Glacial Event with 8 to $15 \mathrm{~m}$ thickness. This non linear aspect appears directly parallel (synchronous) to the co-seismic growth of the vertical component of deep fault scarps. Some sedimentary levels (as PLGE's top) are reference surfaces for detailed tectonic analysis (Mercier de Lépinay et $a l$, 2003). Conversely, the vertical component of fault scarps is often guiding the deep co-seismic sediments arrivals; added to some possible seiche effect, they tend to smoothen the created bottom relieves.

Concerning the upper marine sequence (12000 yr B.P. to Present), such non linear accumulation is not so obvious. The short laminated slightly coarser episodes appear to have recorded earthquake disturbances but not clearly to represent themselves the impact of seismic events; even if considering so, their relative cumulated thickness can not account for a major part of the sedimentation and for the strong lateral thickness increased observed between the two studied sites in the deep Central Basin. As we did not observed repeated true 
hemipelagic interval in this upper part, an apparently permanent silty-sandy flux has to be assumed; an alternative hypothesis is to consider this monotonous, contrast-lacking, accumulation, as the superposition of fine-grained redeposited interval which limits are not visible; only a highly detailed analysis of texture and composition of this sequence will allow to decipher.

Further investigations are in process to improve several proposed conclusions and, overall, precise the time and lateral distribution of the major "event" in the whole Sea of Marmara fro the last 20000 yr. AMS measurements are in process, separately on normal sedimentation and major "events" to check a specific particle array. Detailed study of Cores 25, 27, and 32, in the other deep basins (Tekirdağ, Kumburgaz, Çinarcic) are in process in order to attempt event-by-event correlation. The detailed analysis of terrigenous fraction (through mineralogy) is also necessary to better assume the provenance of reworked material, in order to model huge hyperpycnal flows trajectories and velocities.

\section{Acknowledgements:}

The MARMACORE Cruise is part of GEOSCIENCES Project supported by C.N.R.S.'s Institut National des Sciences de l'Univers; detailed laboratory investigations have been funded be the different involved Laboratories associated to the C.N.R.S.. MARMACORE Scientific Team is grateful to Yvon Balut for successfull management of the giant piston corer. We acknowledge the captain of R/V MARION-DUFRESNE and the whole crew (special thanks to Jean Bart's descendants). We are grateful to J.-M. Daniel, B. Colletta, and J.-M. Mengus for the realization of X-ray scanner images in I.F.P.'s laboratory.

\section{Références:}

Adams J..- (1990) Paleoseismicity of the Cascadian subduction zone: evidence from turbidites off the Oregon-Washington margin. Tectonics, vol. 9, 4:569-583.

Aksu A.E., Hiscott R.N., Yasar D..- (1999) Oscillating Quaternary water levels of the Marmara Sea and vigourous outflow into the Aegean Sea from the Marmara SeaBlack Sea drainage corridor. Marine Geol., 153:275-302.

Aksu A.E., Hiscott R.N., Kaminskie M.A., Mudie P.J., Gillespie H., Abrajano T., Yaşar D..(2002-a) Last glacial-Holocene paleoceanography of the Black Sea and Marmara Sea: stable isotopic, formaminiferal and cocolith evidence. Marine Geology, 190:119-149. 
Aksu A.E., Hiscott R.N., Yaşar D., Isler F.I., Marsh S..- (2002-b) Seismic stratigraphy of Late Quaternary deposits fro the southwetern Black Sea relief: evidence for noncatastrophic variations in sea-level during the last 10000 yr. Marine Geol., 190:61-94.

Alfaro P., Moretti M., \& Soria J.M..- (1997) Soft-sediment deformation structures induced by earthquakes (seismites) in pliocene lacustrine deposits (Guadix-Baza Basin, Central Betic Cordillera). Eclogae geol. Helv., 90:531-540.

Allen J.R.L..- (1986) Earthquake magnitude-frequency, epicentral distance, an soft sediment deformation in sedimentary basins. Sedimentary Geol., 46:67-75.

Allen J.R.L..- (2001) Principles of physical sedimentology. The Blackburn Press 277 pp.. Ambraseys N.N..- (2002) The seismic activity of the Marmara sea region over the last 2000 years. Bull. Seism. Soc. Amer., 92:1-18.

Ambraseys N.N., \& Finkel C.F..- (1991) Long-term seismicity of Istanbul and the Marmara Sea region. Terra Nova, 3:527-539.

Anand I. and Jain A. K..- (1987) Earthquakes and deformational structures (seismites) in Holocene sediments from the Himalayan-Andaman Arc, India. Tectonophysics, 133:105-20.

Armijo R., Meyer B., Hubert A., \& Barka A..- (1999) Westward propagation of the North Anatolian Fault into the northern Aegean: timing and kinematics. Geology, vol. 27, $3: 267-270$.

Armijo R., Meyer B., Navarro S., King G., Barka A..- (2002) Asymetric slip partitioning in the Sea of Marmara pull-apart: a clue to propagation processes of the Anatolian Fault. ? Terra Nova, 14:80-86.

Arnaud F., Lignier V., Revel M., Desmet M., Beck C., Pourchet M., Charlet F., Trentesaux A., \& Tribovillard N..- (2002) Flood and earthquake disturbance of ${ }^{210} \mathrm{~Pb}$ geochronology (Lake Anterne, NW Alps). Terra Nova, Vol. 14, 4:225-232.

Audemard F., De Santis F..- (1991) Survey of liquefaction structures induced by recent moderate earthquakes. Bull. Intern. Assoc. Eng. Geol., 44:5-16.

Barka A..- (1996) Slip distribution along the North-Anatolian fault associated with the largest earthquakes of the period 1939 to 1967. Bull. Seism. Soc. Amer., 86:1238-1254.

Beck C..- (2005) Lacustrine sedimentary records of Late Quaternary seismic activity in the northwestern Alps. Case studies and clues for earthquake-origin assessment of sedimentary disturbances. Submitted for "Paleoseismology" (McAlpin, Audemard, Michetti, Edts.), Geol. Soc. Amer. Memoir.

Beck C., Manalt F., Chapron E., Van Rensbergen P., \& De Batist M.- (1996) Enhanced 
seismicity in the early post-glacial period: evidence from the post-würm sediments of Lake Annecy, northwestern Alps. J. Geodynamics, 22, 1/2, p.155-171.

Beck C., Schneider J.-L., Cremer M., Mercier de Lépinay B., Çagatay N., Labeyrie L., Turon J.-L., Wendenbaum E., Boutareau S., Ménot-Combes G., Hadjas I., Cortijo E., \& MARMACORE Leg Shipboard Scientific Party..- Late Pleistocene major sedimentary reworking event (homogenite) in the Marmara Sea Central Basin : a combination of Late Glacial high terrigenous supply with a major earthquake? Preliminary results of giant piston-coring and high-resolution seismic reflection. $A G U-E G S-E U G$ joint meeting, Nice (April 2003).

Becker A., Davenport C.D., Giardini D..- (2002) Palaeoseimological studies on endPleistocene and Holocene around Basle, Switzerland. Geophys. J. Intern., 149:659-678.

Becker A., Ferry M., Schnellmann M., Giardini D..- (2004) Multiarchive paleoseismic record of late Pleistocene strong earthquakes in Switzerland. Tectonophysics, in press.

Ben-Menahem A..- (1976) Dating historical earthquakes by mud profiles of lake-bottom sediments. Nature, 262:200-202.

Bouma A.H..- (2000) Coarse-grained and fine-grained turbidite systems as end members models: applicability and dangers. Mar. Petrol. Geol., 17 :137-143.

Boutareaud S..- (2003) Etude de l'enregistrement sédimentaire de la sismicité: l'exemple de la Mer de Marmara. Unpublished Master Memoir, University of Bordeaux I.

Bowen A.J., Normak W.R., \& Piper D.J.R..- (1984) Modelling of turbidity currents on Navy Submarine Fan, California continental Borderland. Sedimentology, 31:169-185.

Brown K. \& Berhmann J..- (1990) Genesis and evolution of small-scale structures in the toe of the Barbados Ridge accretionary wedge. In Moore J.C. and Mascle A., et al, Proc. O. D. P., Sc. Results, 110:College Station, TX, 229-244.

Çağatay N., Görür N., Algan O., Eastoe C.J., Tchapalyga A., Ongan D., Kuhn T., Kuscu I..(2000) Late Glacial-Holocene paleoceanography of the Marmara Sea: timing of connections with the Mediterranean and the Black Seas. Marine Geol., 167:191-206.

Çağatay N., Görür N., Polonia A., Demirbag E., Sakinç M., Cormier M.-H., Capotondi L., McHugh C., Emre Ö., Eris K..- (2003) Sea level changes and depositionnal environments in the Izmit Gulf, eastern Marmara Sea, during the late GlacialHolocene period. Marine Geol., 202:159-173.

Calvo J.P., Rodriguez-Pascua M., Martin-Velasquez S., Jimenez S., De Vicente G..- (1998)

Microdeformation of lacustrine laminite sequences from Late Miocene formations of 
SE Spain: an interpretation of loop bedding. Sedimentology, 45:279-292.

Carrillo E., Audemard F., Beck C., Cousin M., Jouanne F., Cano V., Castilla R., Melo L., \& Villemin T..- (2005) A Late Pleistocene natural seismograph along the Boconò Fault (Mérida Andes, Venezuela): the moraine-dammed Los Zerpa paleo-lake. Tectonophysics, in press.

Caselles J.O., Moretti M., Alfarao, Canas J.A., Clapès J..- (1997) Estructuras sedimentarias de deformaciòn (sismitas) inducidas por licuefacciòn con un simulador de terremotos. Geogaceta, Soc. Geol. España, 21 :67-70.

Chapron E..- (1999) Contrôles climatique et sismo-tectonique de la sédimentation lacustre dans l'Avant-Pays Alpin (Lac du Bourget) durant le Quaternaire récent. Géologie Alpine, Mémoire H.S. n³0, Univ. J. Fourier, 261 pp..

Chapron E., Beck C., Pourchet M., Deconinck J.-F..- (1999) 1822 AD earthquake-triggered homogenite in Lake Le Bourget (NW Alps). Terra Nova, 11 :86-92.

Chapron E., Van Rensbergen P., Beck C., De Batist M., \& Paillet.(1996)- Lacustrine sedimentary record of brutal events in Lake Le Bourget (Northwestern Alps-Southern Jura). Quaternaire, 7, 2/3, p. 155-168.

Cita M.B., Camerlenghi A., Rimoldi B..- (1996) Deep-sea tsunami deposits in the eastern Mediterranean: new evidence and depositional models. Sedimentary Geology, $104: 155-173$.

Cita M.B., Rimoldi B..- (1997) Geological and geophysical evidence for a Holocene tsunami deposit in the eastern Mediterranean deep-sea record. J. Geodynamics, 1-4 :293-304.

Cowan D.S..- (1982) Origin of "Vein Structure" in slope sediments on the inner slope of the Middle America Trench off Guatemala. In Aubouin J., von Hene R., et al, Init. Rep. D.S.D.P., 67:Washington, U.S. Govt. Printing Office), 645-650.

De Batist M., Imbo Y., Vermeesch P., Klerkx J., Giralt S., Delvaux D., Lignier V., Beck C., Kalugin I., Abdrakhmatov K.E..- (2002) Bathymetry and sedimentary environments of Lake Issyk-Kul, Kyrghyz Republic (Central Asia): a large, high-altitude, tectonic lake. in «Lake Issyk-Kul : its natural environment» (J. Klerkx \& B. Imanackunov, Eds.), NATO Science Series IV, Kluwer Academic Publ., 13 :101-124.

Demirbağ E., Rangin C., Le Pichon X., ’ engör A.M.C..- (2003) Investigations of the tectonics of the Main Marmara Fault by means of deep-towed seismic data. Tectonophysics, 361:1-19.

Doig R..- (1985) A method for determining the frequency of large-magnitude earthquakes using lake sediments. Can. J. Earth Sci., 23:930-937. 
Doig R..- (1991) Effects of strong seismic shaking in lake sediments, and earthquake recurrence interval, Temiscaming, Québec. Can. J. Earth Sci., 28 :1349-1352.

Dolan J., Beck C., Ogawa Y..- (1989) Upslope deposition of extremely distal turbidites: an example from the Tiburon Rise, west-central Atlantic. (1989) Geology, vol. 17, pp. 990-994.

El-Isa Z. H., Mustafa H..- (1986) Earthquake deformations in the Lisan deposits and seismotectonic implications. Geophys. J. R. astr. Soc., 86:413-424.

Ergin M., Bodur M.N. and Ediger V..- (1991) Distribution of surficial shelf sediments in the northeastern and southwestern parts of the Sea of Marmara: Straits and canyon regimes of the Dardanelles and Bosphorus. Marine Geology, Volume 96, pages 313340 .

Ergin M., Kapur S., Karakas Z., Akca E., Kangal Ö. and Keskin · ..- (1999) Grain size and clay mineralogy of Late Quaternary sediments on a tectonically active shelf, the southern Sea of Marmara: clues to hydrographic, tectonic and climatic evolution. Geological Journal, Volume 34, pages 199-210.

Field M. E., Gardner J. V., Jennings A. E., Edwards B. D..- (1982) Earthquake-induced sediment failure on a $0.25^{\circ}$ slope, Klamath River delta, California. Geology, 10:542546.

Föhlisch K. \& Voigt T..- (2001) Synsedimentary deformation in the Lower Muschelkalk of the Germanic Basin. In "Particulate Gravity Currents “, W.D. McCaffrey, B.C. Kneller, \& J. Peakall, Edts., Intern. Ass. Sedimentologists Spec. Publ., Blackwell Science, Vol. 31, p. 279-297.

Gorsline D.S., De Diego T., \& Nava-Sanchez E.H..- (2000) Seismically triggered turbidites in small margin basins : alfonso Basin, Western Gulf of California and Santa Monica Basin, California Borderland. Sediment. Geol., 135 :21-35.

Guiraud M. \& Plaziat J.-C..- (1993) Seismites in the fluvial Bima sandstones: identificatin of paleoseisms and discussion on their magnitude in a Cretaceous synsedimentary strikeslip basin (upper Benue, Nigeria). Tectonophysics, 225:493-522.

Hempton M.R., Dewey J.F..- (1983) Earthquake-induced deformational structures in young lacustrine sediments, East Anatolian Fault, southwest Turkey. Tectonophysics, 98:714.

Hiscott R.N., Aksu A.E..- (2002) Late Quaternary history of the Marmara Sea and Black Sea from high-resolution seismic and gravity-core studies. Marine Geology, 190:261-282. Hubert-Ferrarri A., Barka A., Jacques E., Nalbant S.S., Meyer B., Armijo R., Tapponier P., 
King G.C.P..- (2000) Seismic hazard in the Marmara Sea region following the 17 August 1999 Izmit earthquake. Nature, 404:269-273.

Ǐmren C., Le Pichon X., Rangin C., Demirbağ E., Ecevitoğlu B., Görur N..- (2001) The north Anatolian fault within the Sea of Marmara: a new interpretation based on multichannel seismic and multi-beam bathymetry data. Earth Planet. Sc. Lett., 186:143158.

Kastens K. \& Cita M.B..- (1981) Tsunami-induced sediment transport in the abyssal Mediterrranean Sea. Geol. Soc. Amer.Bull., 92:845-857.

Kuenen P.H..- (1958) Experiments in geology. Trans. Geol. Soc. Glasgow, 23:1-28.

Komar P.D..- (1971) Hydraulic jumps in turbidity currents. Geol. Soc. Amer. Bull., 82:14771488 .

Kubo Y. \& Yokokawa M..- (2001) Theoretical study on breaking of waves on antidunes. In "Particulate Gravity Currents “, W.D. McCaffrey, B.C. Kneller, \& J. Peakall, Edts., Intern. Ass. Sedimentologists Spec. Publ., Blackwell Science, Vol. 31, p. 65-70.

Le Pichon X., Sengor A.M.C., Demirbag E., Rangin C., Imren C., Armijo R., Gorur N., N. Çagatay, Mercier de Lépinay B., Meyer B., Saatcilar R., Tok B..- (2001) The active main Marmara Fault. Earth Planet. Sc. Lett., 192 :595-616.

Lignier V..- (2001) Les sédiments lacustres et l'enregistrement de la paléoséismicité.Etude comparative de différents cas dans le Quaternaire des Alpes Nord-Occidentales et du Tien-Shan Kyrghize. Unpublished Doct. Thesis, University of Savoy.

Lignier V., Beck C., Chapron E..- (1998) Caractérisation géométique et texturale de perturbations synsédimentaires attribuées à des séismes, dans une formation quaternaire glaciolacustre des Alpes (les "Argiles du Trièves"). C. R. Acad. Sc. Paris, $327: 645-652$.

Major C., Ryan W., Lericolais G., Hadjas I..- (2002) Constraints on Black Sea outflow to the Sea of Marmara during the last glacial-interglacial transition. Marine Geology, 190:19-34.

McClusky S., Bassalanian S., Barka A., Demir C., Ergintav S., Georgiev I., Gurkan O., Hamburger M., Hurst K., Hans-Gert H.-G., Karstens K., Kekelidze G., King R., Kotzev V., Lenk O., Mahmoud S., Mishin A., Nadariya M., Ouzounis A., Paradissis D., Peter Y., Prilepin M., Relinger R., Sanli I., Seeger H., Tealeb A., Toksöz M.N., Veis G..- (2002) Global positioning system constraints on plate kinematics and dynamics in the eastern Mediterranean and Caucasus. Journ. Geophys. Res., 105:5695-5719. 
Marco S. \& Agnon A.- (1995) Prehistoric earthquake deformations near Masada, Dead Sea Graben. Geology, vol. 23, 8 :695-698.

Mercier de Lépinay B., L. Labeyrie, N. Çagatay, and MARMACORE Scientific Team. (2001) IFRTP unpublished shipboard report, 34 p.

Mercier de Lépinay B., L. Labeyrie , N. Çagatay , C. Beck , J.-L. Schneider , M. Cremer, J.-L. Turon , L. Londeix , B. Meyer , Y. Gallet , N. Pondard , G. MénotCombes , I. Hadjas , E. Cortijo . Interplay between recent sedimentation and active tectonics in Marmara Sea. AGU-EGS-EUG joint meeting, Nice (April 2003).

Moretti M., Alfaro P., Caselles O., Canas J.A..- (1999) Modelling seismites with a digital shaking table. Tectonophysics, 304:369:383.

Moretti M. \& Tropeano M..- (1996) Strutture sedimentarie deformative (sismiti) nei depositi tirreniani di Bari. Mem. Soc. Geol. It., 51:485-500.

Mörner N.-A..- (1996) Liquefaction and varve deformation as evidence of paleoseismic events and tsunamis. The autumn 10,430 BP case in Sweden. Quaternary Sc. Rev., 15:939-948.

Mulder T. \& Cochonat P..- (1996) Classification of offshore mass movements. J. Sediment. Res., vol. 66, 1:43-57.

Mulder T., Tisot J.-P., Cochonat P., \& Bourillet J.-F..- (1994) Regional assessment of mass failure events in the Baies des Anges, Mediterranean Sea. Marine Geol., vol. 122, 1/2: $29-45$.

Nakajima T. \& Kanai Y..- (2000) Sedimentary features of seismoturbidites triggered by the 1983 and older historical earthquakes in the eastern margin of the Japan Sea. Sediment. Geol., 135:1-19.

Nemec W..- (1990) Aspects of sediment movement on steep delta slopes. In "Particulate Gravity Currents “, A. Colella \& D.B. Prior, Edts., Intern. Ass. Sedimentologists Spec. Publ., Blackwell Science, Vol. 10, p. 29-73.

Obermeier S..- (1989) The New Madrid earthquakes: an engineering-geologic interpretation of relict liquefaction features. U.S. Geol. Surv. Profess. Pap., 1336-B, 114 p..

Obermeier S.F., Bleuer N.R., Munson C.A., Munson P.J., Martin W.S., McWilliams K.M., Tabaczynski, Odum J.K., Rubin M., \& Eggert D.L..- (1991) Evidence of strong earthquake shaking in the lower Wabash valley from prehistoric liquefaction features. Science, 251:1061-1063.

Ogawa Y., \& Miyata Y..- (1985) Vein structure and its deformation history in the sedimentary 
rocks off the Middle America Trench off Guatemala. Init. Rep. D.S.D.P., 84:Washington, U.S. Govt. Printing Office), 811-829.

Pickering K.T. \& Hiscott R.N..- (1985) Contained (reflected) turbidity currents in the Middle Ordovician Cloridorme Formation, Québec, Canada: an alternative to the antidune hypothesis. Sedimentology, 32:373-394.

Piper D.J.W., Cochonat P., Ollier G., Le Drezen E., Morrison M, Baltzer A..- (1992)

Evolution progressive d'un glissement rotationnel en un courant de turbidité : cas du séisme de 1929 des Grands Bancs (Terre Neuve). C.R. Acad. Sc. Paris, 314:10571064.

Plaziat J.-C., Purser B.H., Philobbos E..- (1988) Diversity of Neogene seismites of the NW Red Sea (Egypt): a characteristic sedimentary expression of rifting. Tectonophysics, 153:295.

Pratt B.R..- (1998) Syneresis cracks: subaqueous shrinkage in argillaceous sediments caused by eathquake-induced dewatering. Sediment. Geol., 117:1-10.

Rangin C., Demirbag E., Imren C., Crusson A., Normand A., Le Drezen E., \& Le Bot A..(2001) Marine Atlas of the Sea of Marmara (Turkey). IFREMER; ISBN 2-84433-068-1.

Ringrose P.S..- (1989) Paleoseismic (?) liquefaction event in late Quaternary lake sediments at Glen Roy, Scotland. Terra Nova, 1:57-62.

Rodriguez-Pascua M.A., Calvo J.P., De Vicente G., \& Gòmez-Gras D..- (2002) Soft-sediment deformation structures interpreted as seismites in lacustrine sediments of the Prebetic Zone, SE Spain, and their potential use as indicators of earthquake magnitudes during the Late Miocene. Sedimentary Geol., vol. 135, 1-4 :117-135.

Roep T.B. \& Everts A.J..- (1992) Pillow-beds: a new type of seismite ? An example from an Oligocene turbidite fan complex, Alicante, Spain. Sedimentology, 39:711-724.

Ryan W.B.F., Pitman W.C., Major C.O., Shimkus K., Moskalenko V., Jones G.A., Dimitrov P., Görür N., Sakinç M., Yüce H..- (1997) An abrupt drowning of the Black Sea shelf. Marine Geol., 138:119-126.

Séguret M., Labaume P., Madariaga R..- (1984) Eocene seismicity in the Pyrénées from megaturbidites of the South Pyrenean basin (Spain). Marine Geology, $55: 117-131$.

Seilacher A. - (1984) Sedimentary structures tentatively attributed to seismic events. Marine Geol., 55:1-12.

Shiki T., Kumon F., Inouchi Y. Kontani Y., Sakamoto T., Tateishi M., Matsubara H., 
Fukuyama K..- (2000) Sedimentary features of the seismo-turbidites, Lake Biwa, Japan. Sediment. Geol., 135:37-50.

Siegenthaler C., Finger W., Kelts K., Wang S..- (1987) Earthquake and seiche deposits in Lake Lucerne, Switzerland. Eclog. geol. Helv., 80:241-260.

Sims J..- (1973) Earthquake-induced structures in sediments of Van Norman Lake, San Fernando, California. Science, 182:161-163.

Sims J..- (1975) Determining earthquake recurrence intervals from deformational structures in young lacustrine sediments. Tectonophysics, 29 :141-152.

Stanley D.J..- (1981) Unifites: structureless muds of gravity-flow origin in Mediterranean basins. Geo-Mar. Lett., 1:77-83.

Stanley D.J. \& Maldonado A..- (1981) Depositional models for fine-grained sediments in the western Hellenic Trench, Eastern Mediterranean. Sedimentology, 28:273-290.

Stein R.S., Barka A., Dieterich J.H..- (1997) Progressive failure on the North Anatolian Fault since 1989 by earthquake stress triggering. Geophys. J. Intern., 128:594-604.

Stow D.AV. \& Wetzel A..- (1990) Hemiturbidite: a new type of deep-water sediment. Proc. Ocean Drilling Program, vol. 105B, pp. 25-34.

Stuiver M., Reimer P.J., Bard E., Beck J.W., Burr G.S., Hugen K.A., Kromer B., McCormac G., Van der Plicht J., Spurk M..- (1998) INTCAL 98 Radiocarbon age calibration, 24 000-0 cal BP. Radiocarbon, 40:1041-1083.

Syvitski J.P.M., Schafer C.T..- (1996) Evidence for an earthquake-triggered basin collapse in Saguenay Fjord, Canada. Sedimentary Geology, 104:127-153.

Tolun L., Çağatay M.N., Carrigan W.J..- (2002) Organic geochemistry and origin of Late Glacial-Holocene sapropelic layers and asociated sediments in Marmara Sea. Marine Geology, 190:47-60.

Tuttle M. \& Seeber L..- (1991) Historic and prehistoric earthquake-induced liquefaction in Newbury, Massachusetts. Geology, 19:594-597.

Van Loon A.J., Brodzikowski K., Zielinski T..- (1995) Shock-induced resuspension deposits from a pleistocene proglacial lake (Kleszczow graben, central Poland). J. Sedimentary Res., vol. 65, 2 :417-422.

Vittori E., Labini S., Serva L..- (1991) Paleoseismology : review of the state of the art. Tectonophysics, 193 :9-32.

Wong H.K., Lüdmann T., Ulug A., \& Görür N..- (1995) The Sea of Marmara: a plate boundary sea in an escape tectonic regime. Tectonophysics, 244:231-250.

Yalçiner A.C., Alpar B., Altinok Y., Özbay İ., Imamura F..- (2002) Tsunamis in the Sea of 
Marmara historical documents for the past, models for the future. Marine Geology, 190:445-463.

\section{FIGURES CAPTIONS}

Figure 1 - Present day geodynamic settings of the Sea of Marmara. (after Armijo et al, 1999, 2002).

Figure 2 - High resolution seismic reflection grid and coring locations of MARMACORE and MARMARASCARPS cruises.

Figure 3 - Summary of giant piston coring results in the Marmara Sea (MARMACORE Cruise), and shipboard proposed lateral correlations.

Figure 4 - Synthetic seismic logs of Cores MD01-2429 (A) and MD01-2431 (B): location of main potential reflective sedimentary interfaces (left) and correlation with detected reflectors (right). The marine upper part correspond to variable amplitude and variable frequency; the lacustrine "hemipelagic-type" lower part correspond to almost constant amplitude and high frequency.

Figure 5 - Close-ups of split sections of the lower lacustrine part of Cores MD01-2429 and MD01-2431, displaying the frequency of strong contrast interfaces between the "hemipelagic-type" permanent sediment and coarse redepositional events.

Figure 6- Detailed morpho-bathymetry of the Marmara Sea's Central Basin, location of giant piston cores and seismic profiles.

Figure 7- 3,5 kHz profiles across the Central Basin, evidencing a "homogenite".

Figure 8- General view of splitted Core MD01-2431, showing the pre-Late Glacial "homogenite" and associated coarse gravity deposits.

Figure 9- Correlations between Cores MD01-2431 and MD01-2429 based on magnetic susceptibility.

Figure 10- Vertical evolution of grain-size distribution in the pre-Late Glacial "event".

Figure 11 - Close ups of selected portions of Core MD01-2431. (a: conjugated microfractures; b: microfracturing with possible sealing by coeval turbidite arrival; c; possible in situ liquefaction, evidenced by ball-and-pillow - b-a-p - structure; $d$ to g: details of the pre-Late Glacial event) 
Figure 12- Schematic genetic model proposed for the pre-Late Glacial Event and similar minor events. The three cases correspond to the three situations observed at the base of major turbiditic events: without underlying disturbance, with underlying fracturation and/or liquefaction, with underlying mudclasts breccia. (the true dip of the source slope is about $\left.6,5^{\circ}\right)$.

Figure 13- Different explanatory models for the segregation of homogenite layers.

Figure 14- 3,5 kHz correlations between Cores MD01-2429 and MD01-2431 evidencing the whole pile (lacustrine and marine) thickness increase. (location and depth of the two sites on Fig. 6)

Figure 15- X-ray SCOPIX close ups of possible earthquake-related disturbances in the upper (Holocene marine) part of Cores MD01-2429 and MD01-2431. Two mechanisms can be deduced: effect of to-and-fro bottom currents on silt (seiche ?), water escape with horizontal offset (lateral shear by shaking ?). 


\begin{tabular}{|c|c|c|c|c|c|}
\hline Sample & Type & $513 \mathrm{C}$ & Age & Age error & Calibrated age BP, 95,4\% conf. \\
\hline MDO12425-2816 cm & Plant/Wood & -26.81 & 12850 & 55 & $15950 / 14350$ yr \\
\hline MD012425-3105 cm & Plant/Wood & -26.6 .6 & 13250 & 55 & $16450 / 14950 \mathrm{yr}$ \\
\hline MD012427-2498 cm & Charcoal & -27.82 & 13600 & 55 & $16850 / 15800 \mathrm{yr}$ \\
\hline MD012428-696 cm & Charcoal & -28.83 & 17200 & 70 & $21150 / 19750 \mathrm{yr}$ \\
\hline \multirow[t]{3}{*}{ MD012429-2705 сाт } & \multirow[t]{3}{*}{ Charcoal } & \multirow[t]{3}{*}{-26.45} & \multirow[t]{3}{*}{9530} & \multirow[t]{3}{*}{45} & $11100 / 10920$ yr $(44,7 \%)$ \\
\hline & & & & & $10910 / 10670$ yr $(49,5 \%)$ \\
\hline & & & & & $10660 / 10640$ yr $(1,2 \%)$ \\
\hline MD012431-1138 cm & Charcoal & -28.12 & 12150 & 65 & $15650 / 14250 y r$ \\
\hline MD012431-1518 cm & Plant/Wood & -27.86 & 13100 & 55 & $16250 / 14750 \mathrm{yr}$ \\
\hline MD012431-1661 cm & Plant/Wood & -28.74 & 14100 & 75 & $17450 / 16350 \mathrm{yr}$ \\
\hline
\end{tabular}




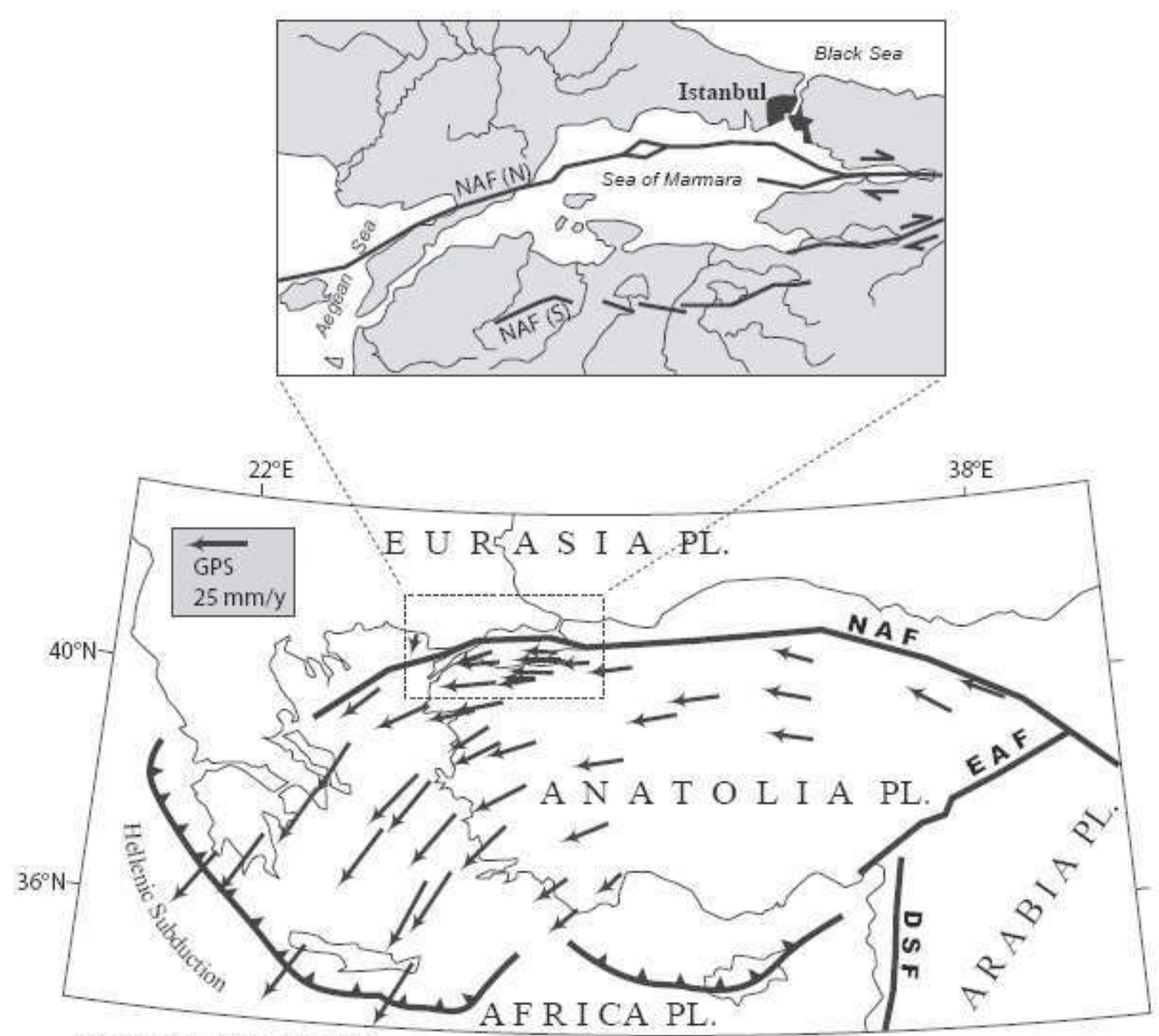

NAF: North Anatolian Fault

EAF: East Anatolian Fault

DSF: Dead Sea Fault 


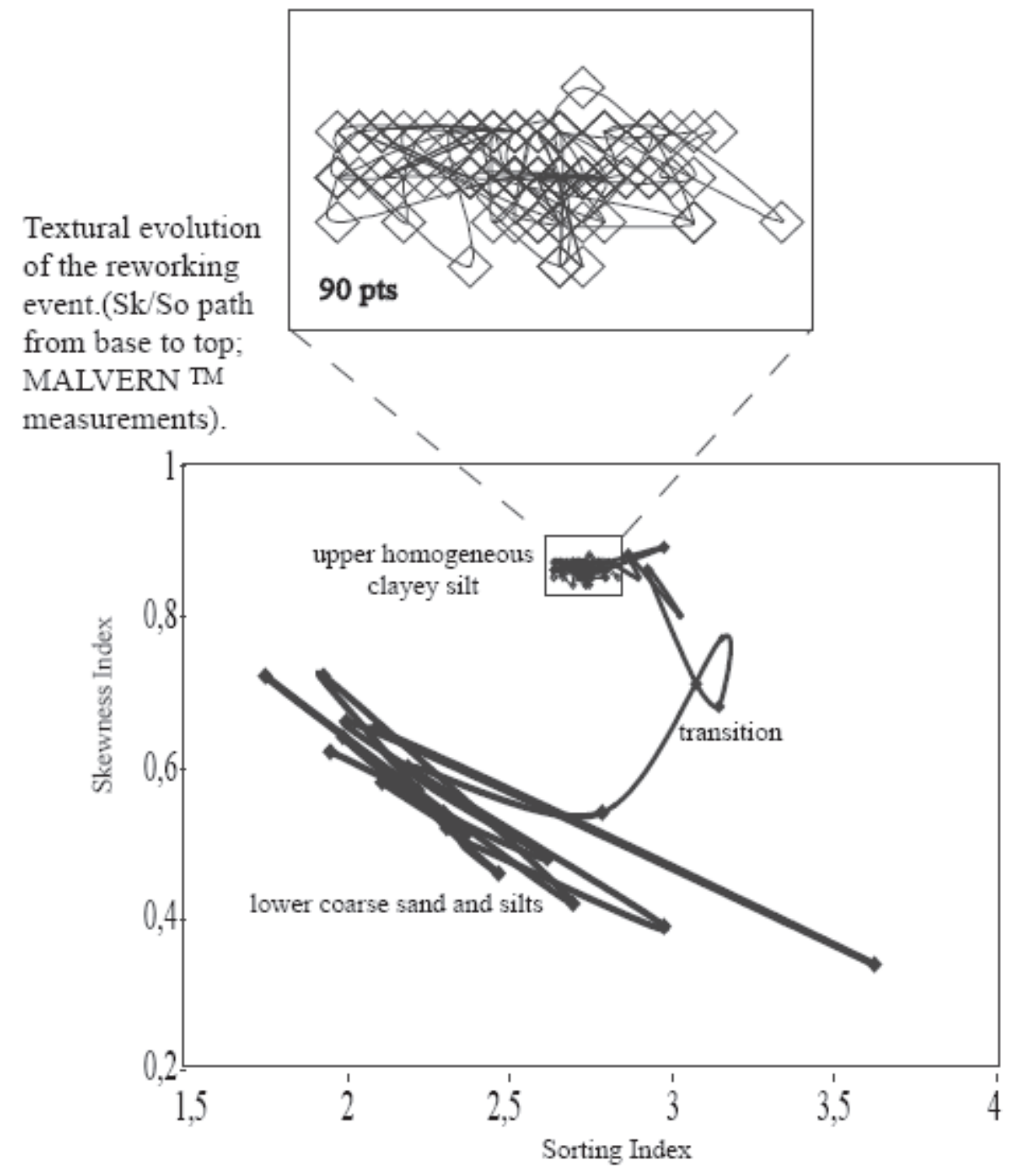



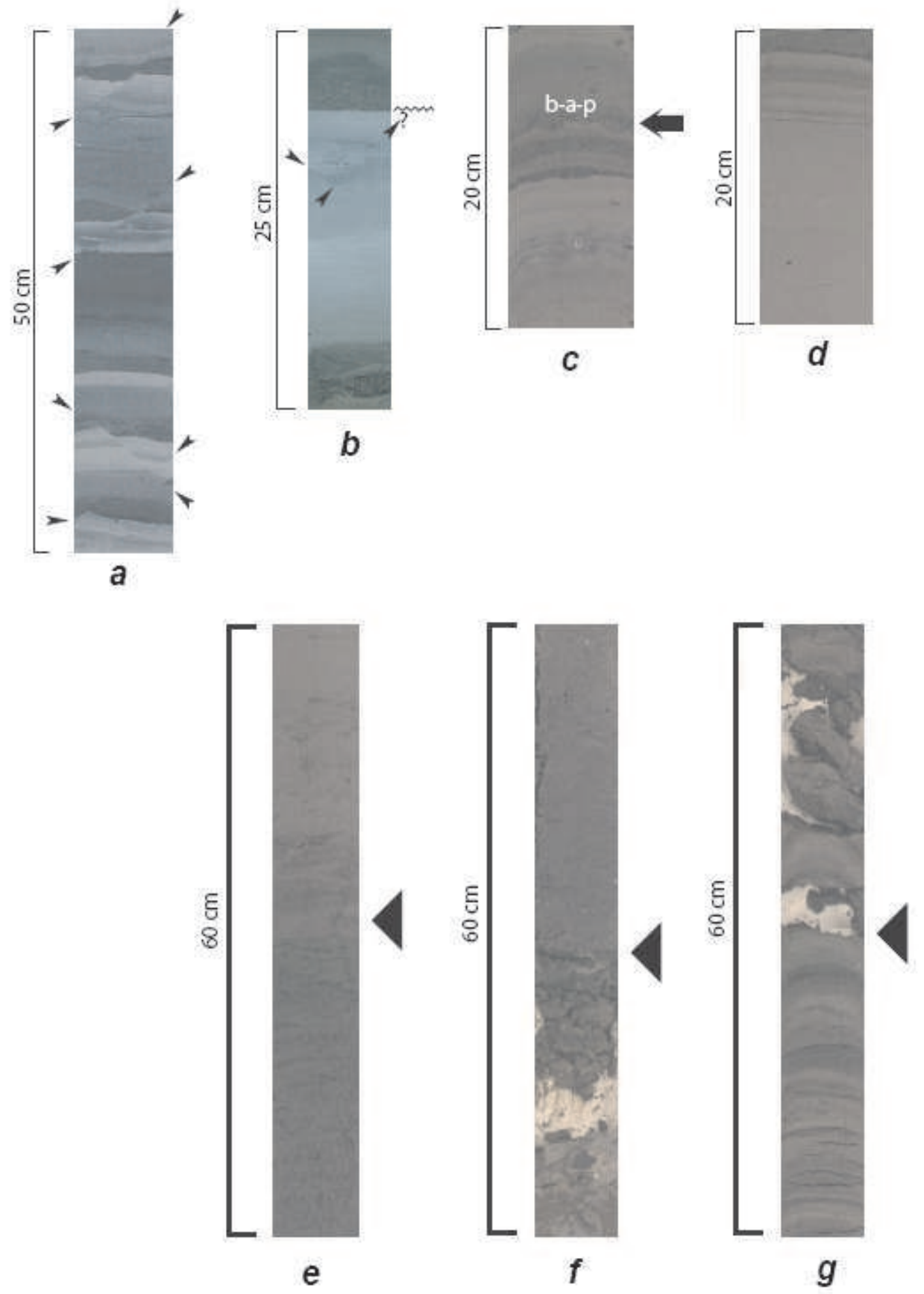

CORE MD01-2431 


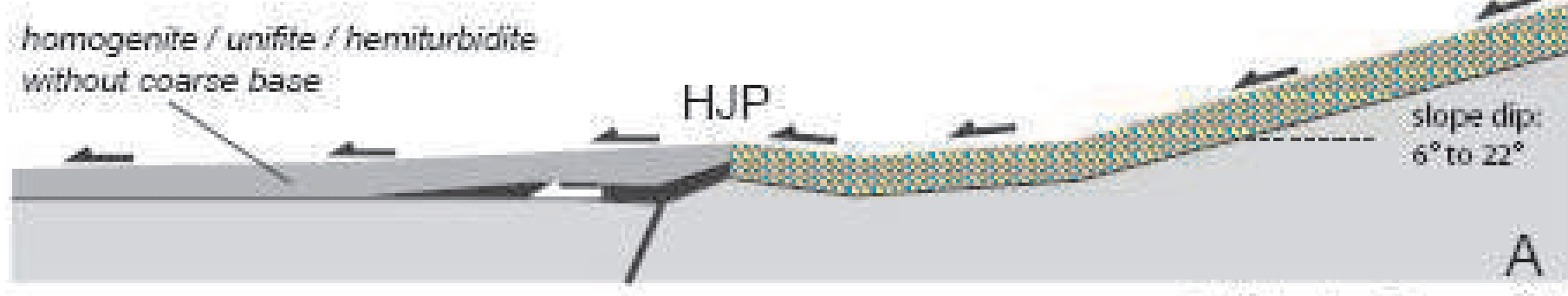

HJP: hydraulo fump point

homogenite / unifite

with coarse base
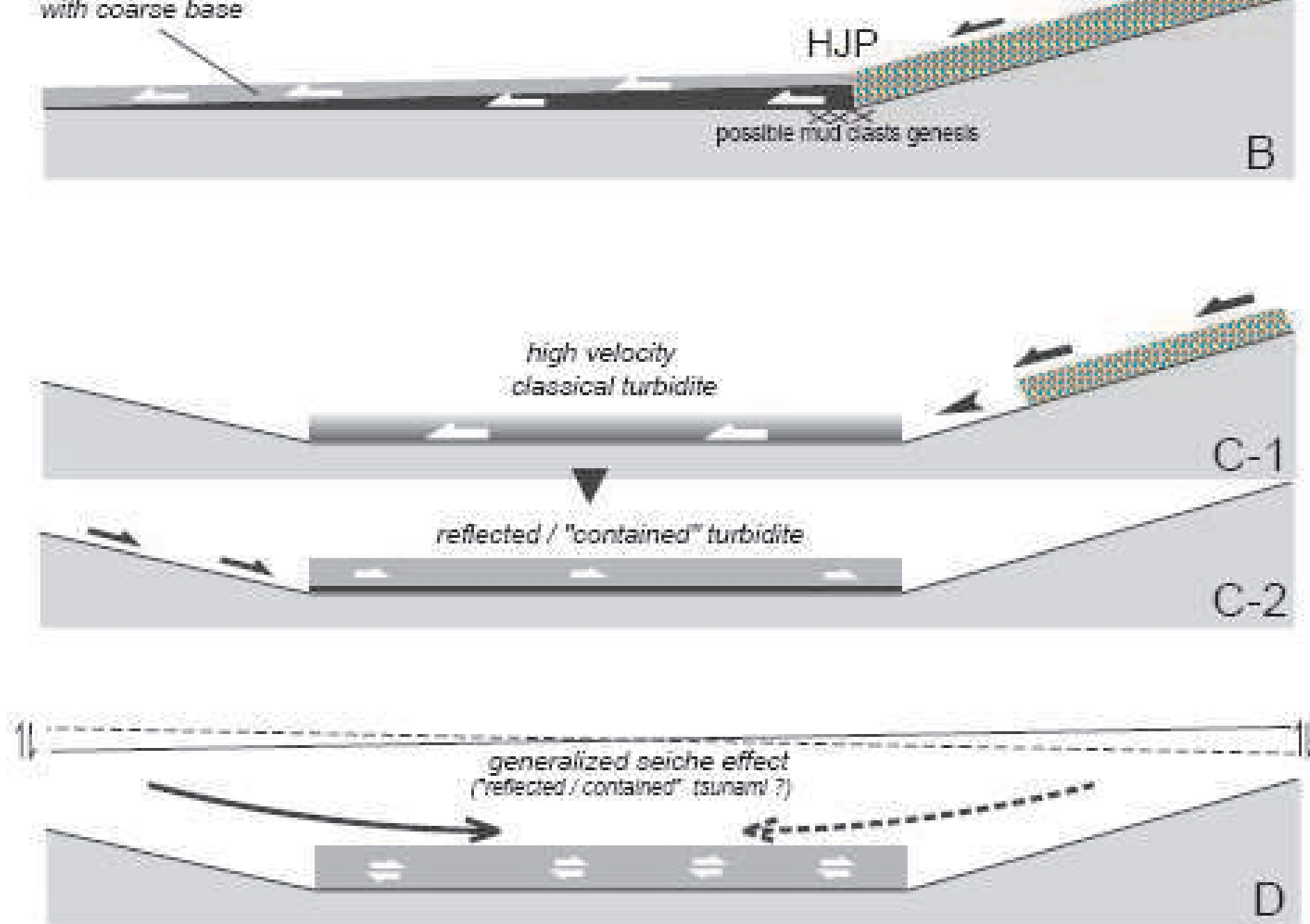


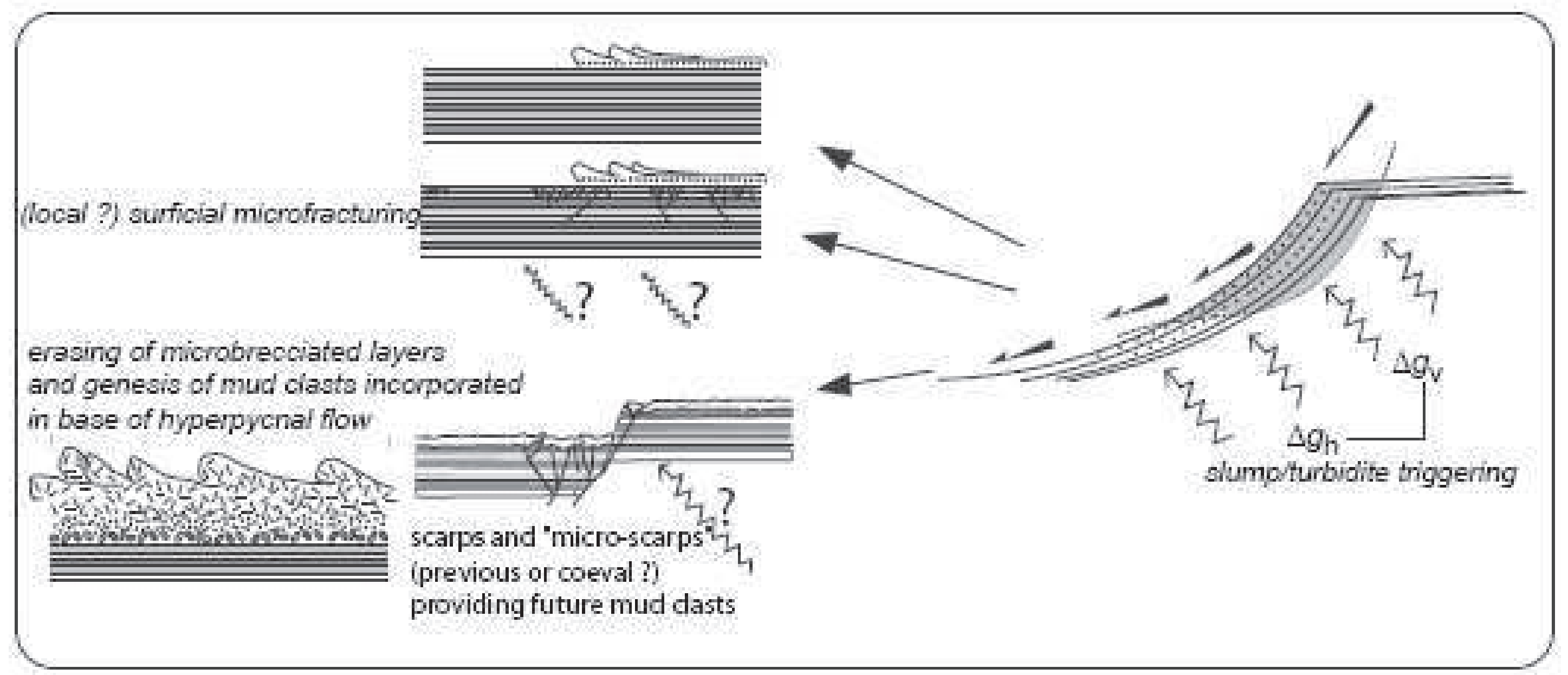




\section{Core MD 2431}

Core MD 2429

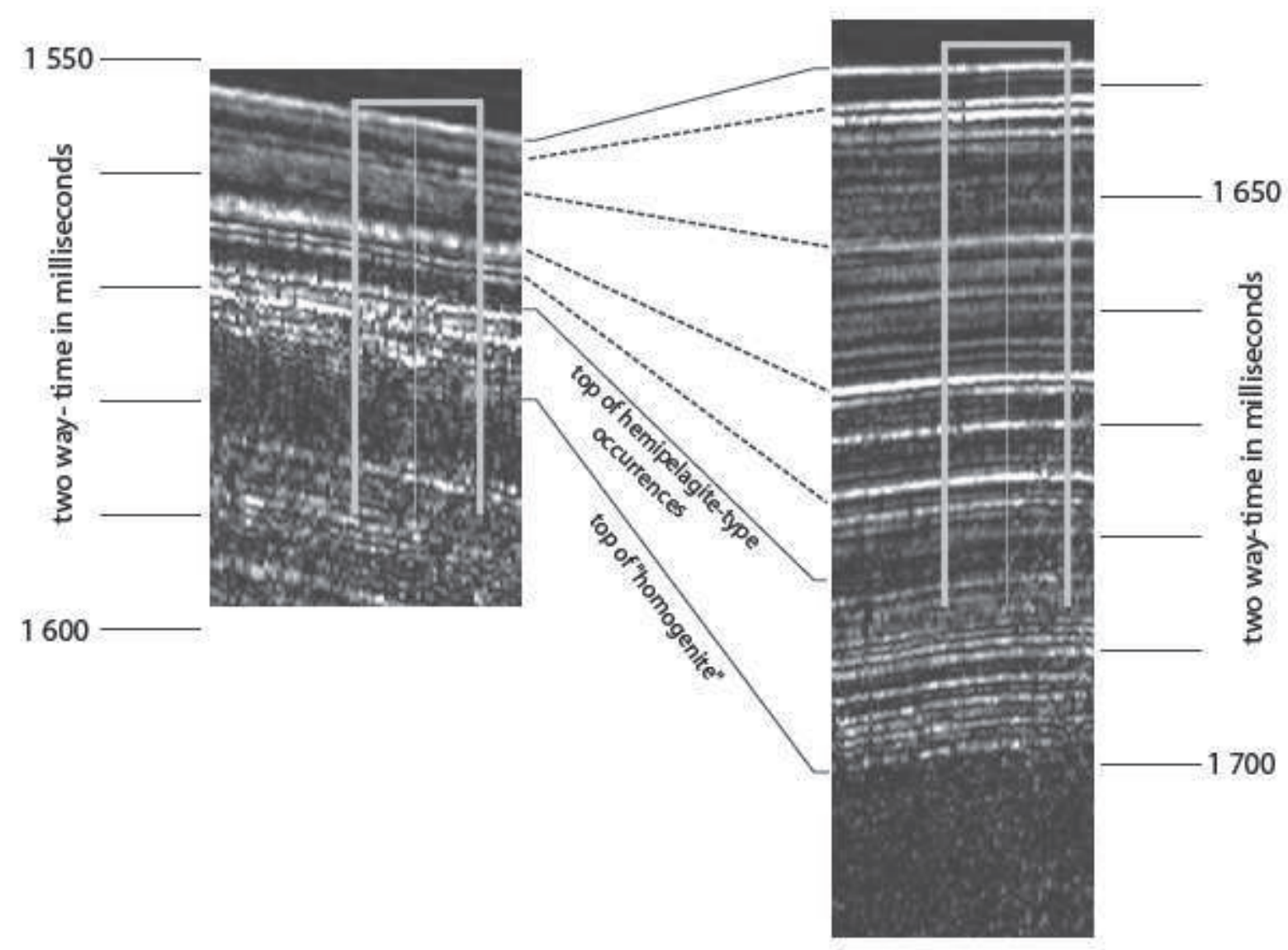




\section{Core MD01-2429}
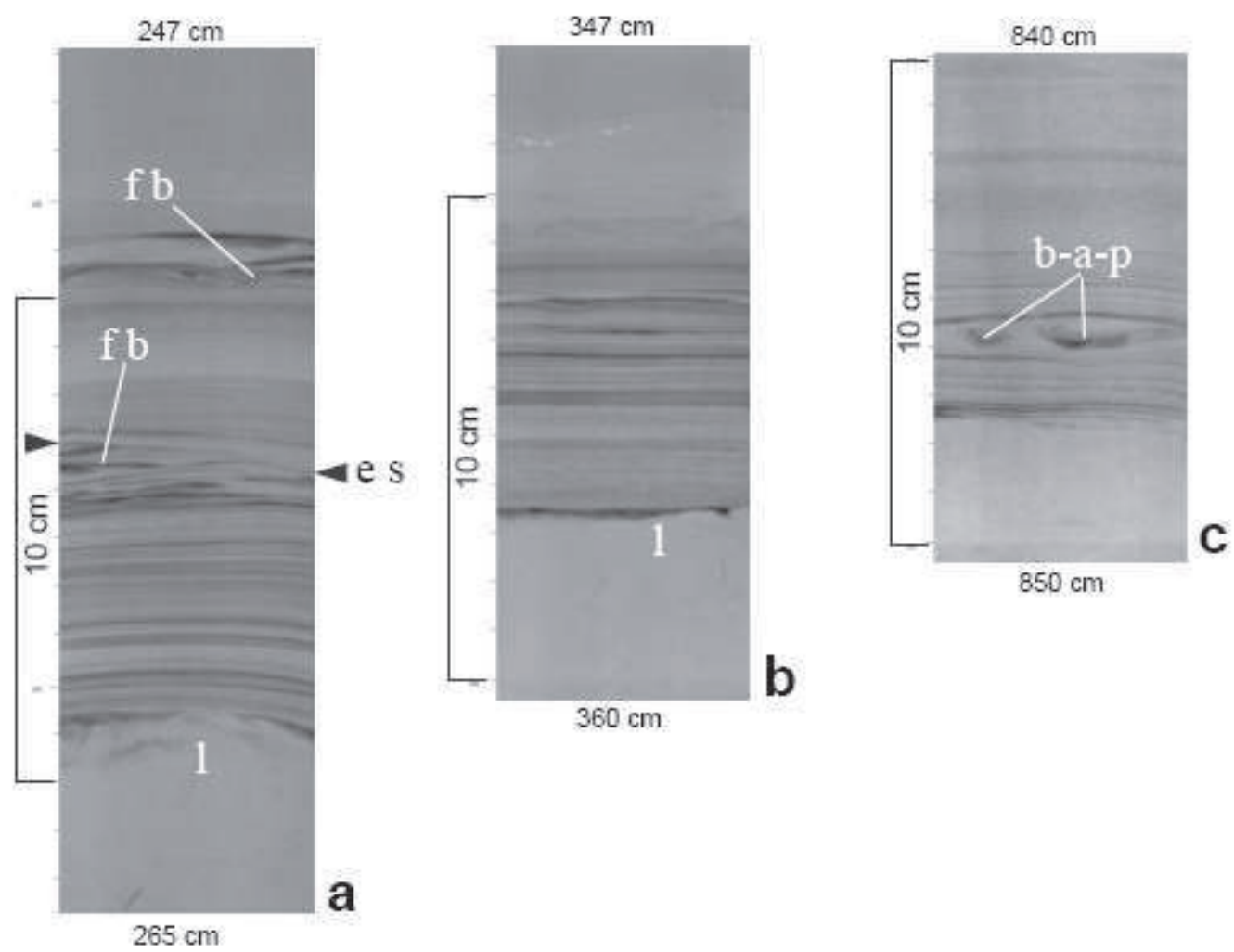

Core MD01-2431
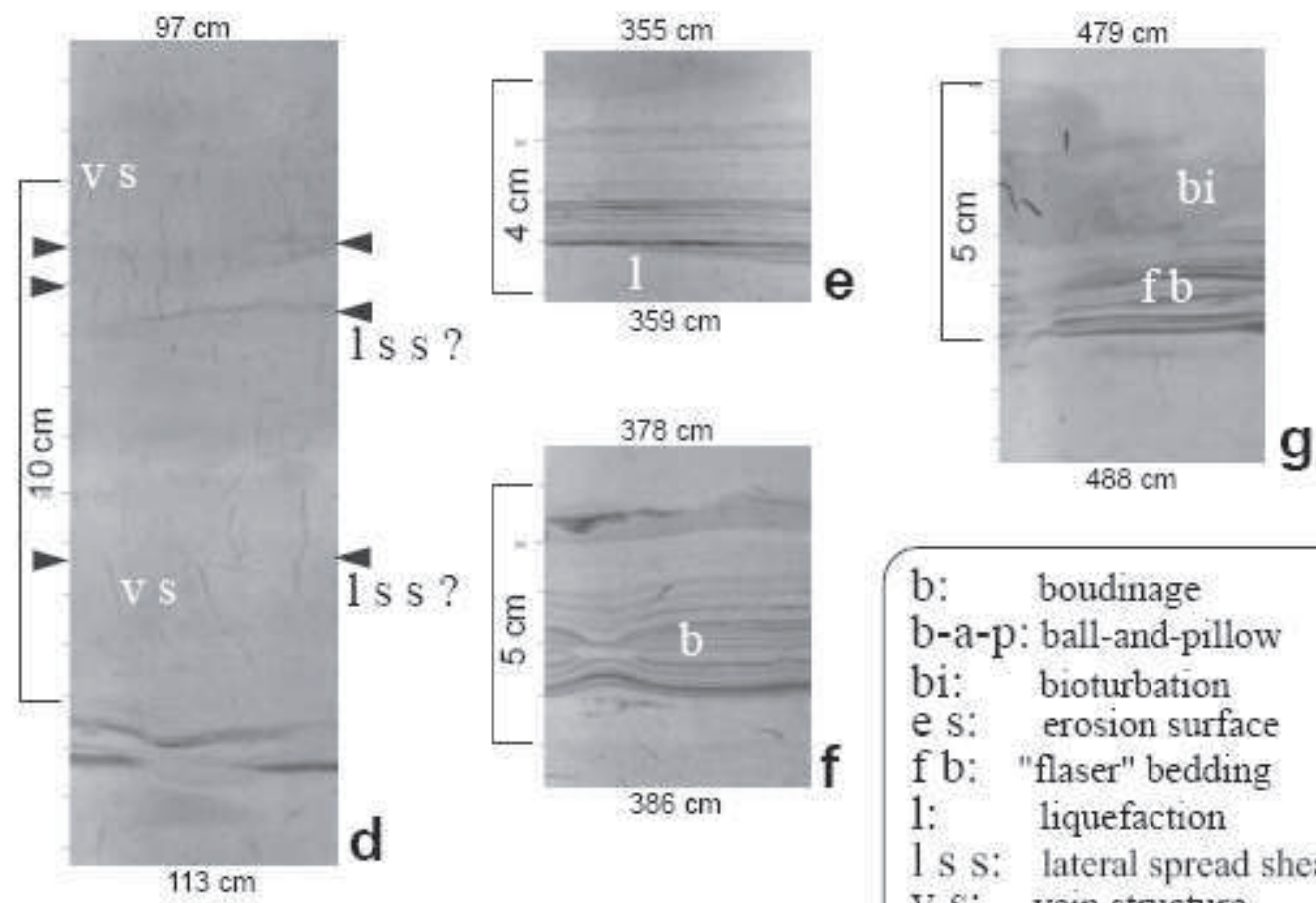

$\mathrm{b}$ : boudinage

b-a-p: ball-and-pillow

bi: bioturbation

e s: erosion surface

$\mathrm{f} \mathrm{b}$ : "flaser" bedding

1: liquefaction

1s s: lateral spread shear V S: vein structure 


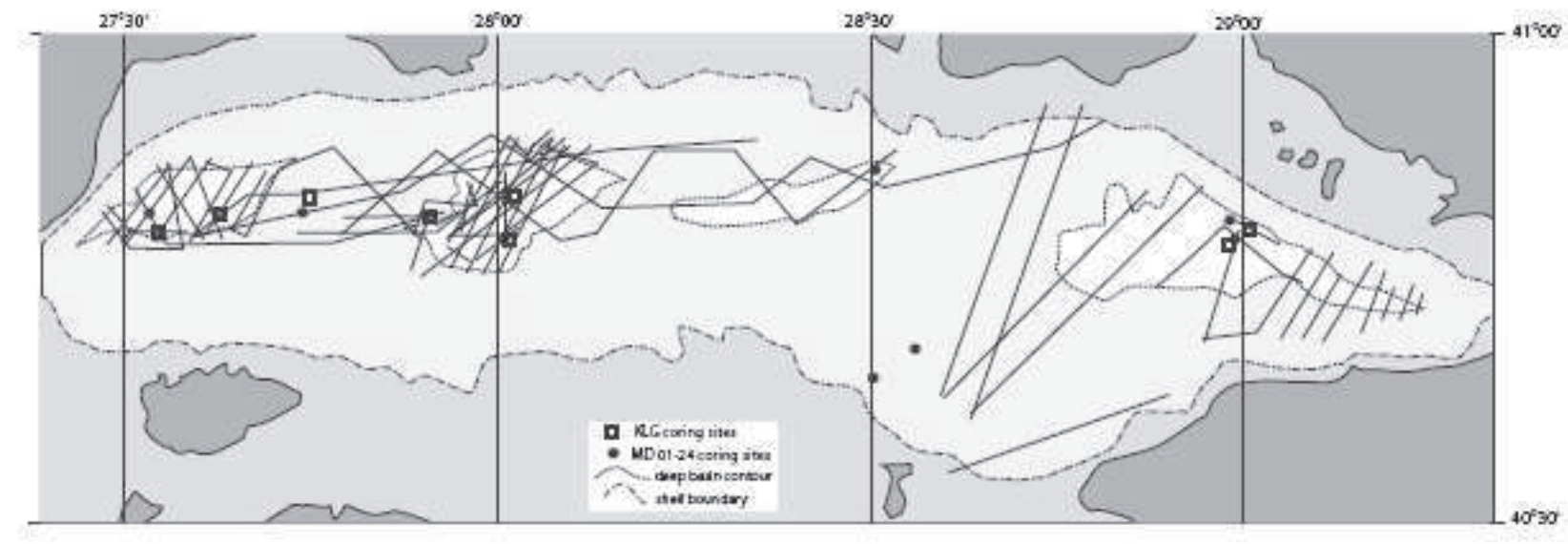




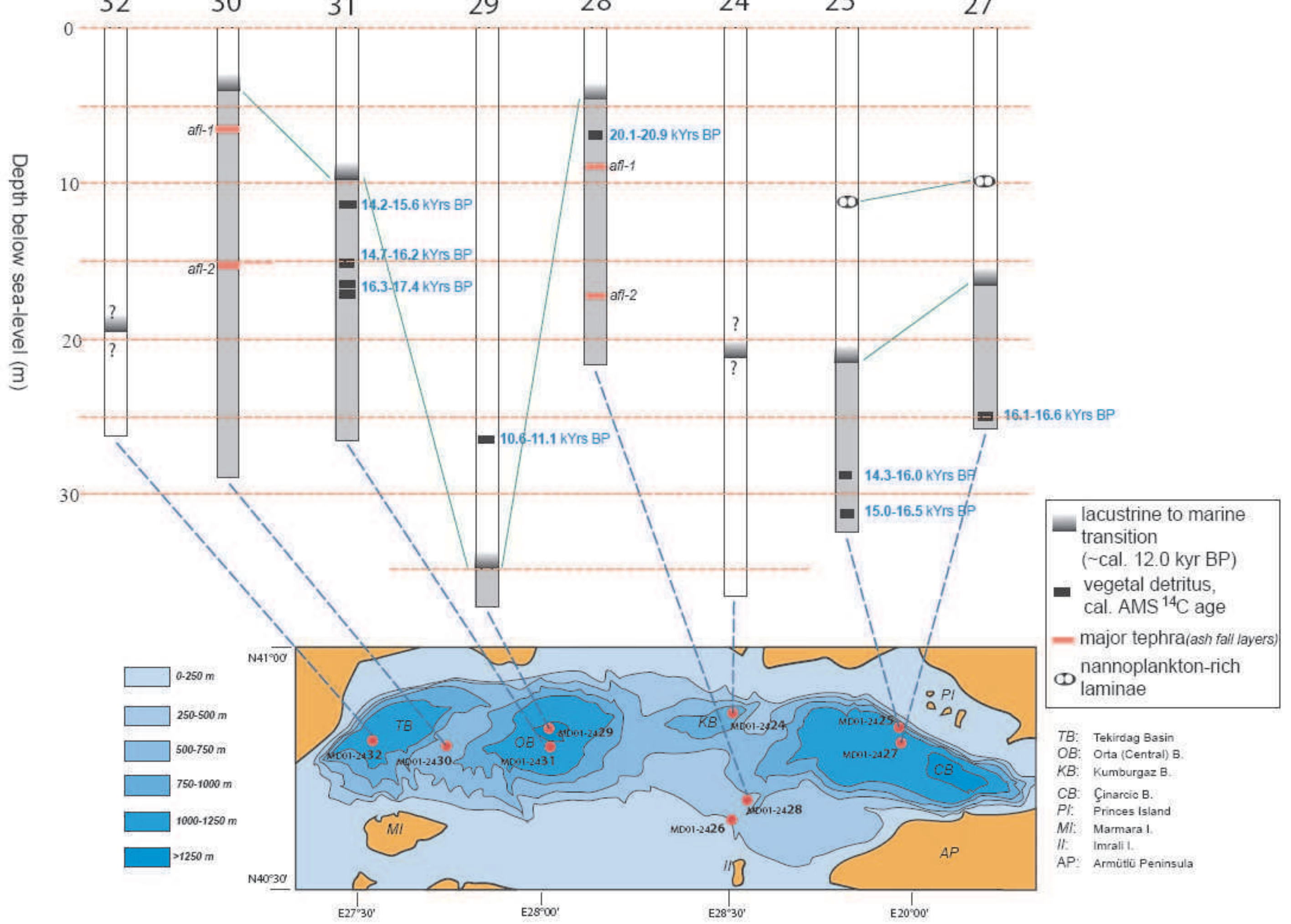




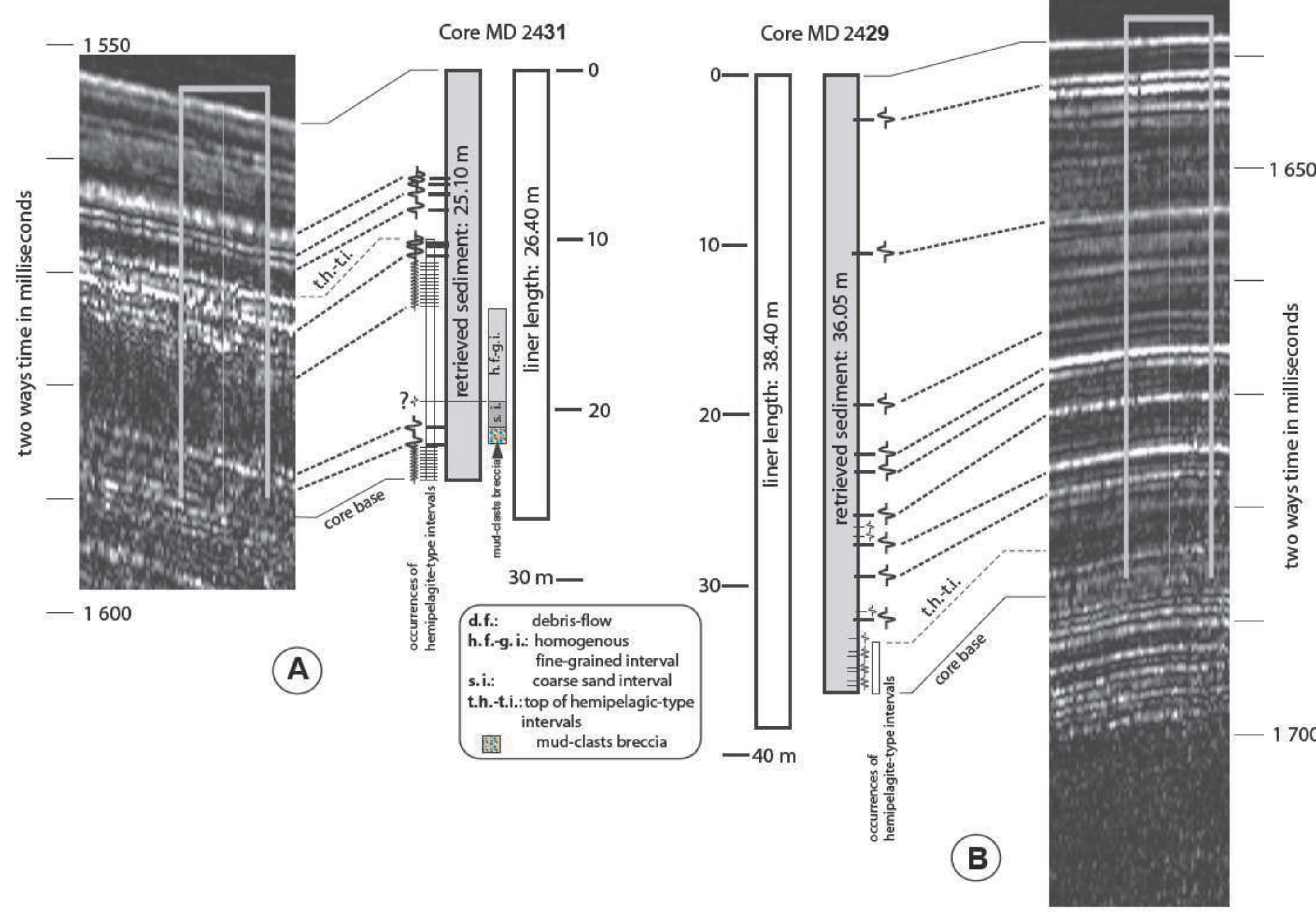




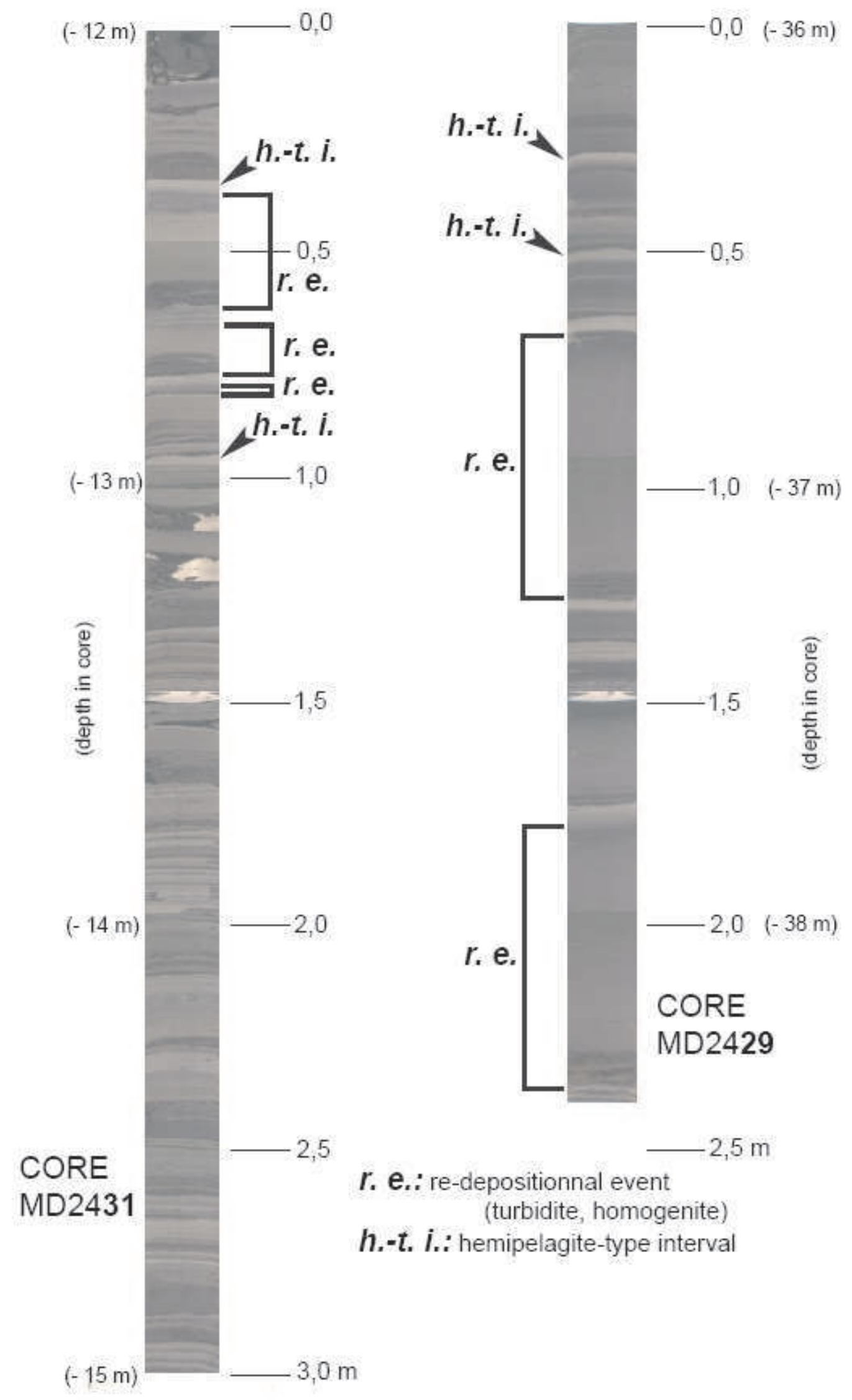




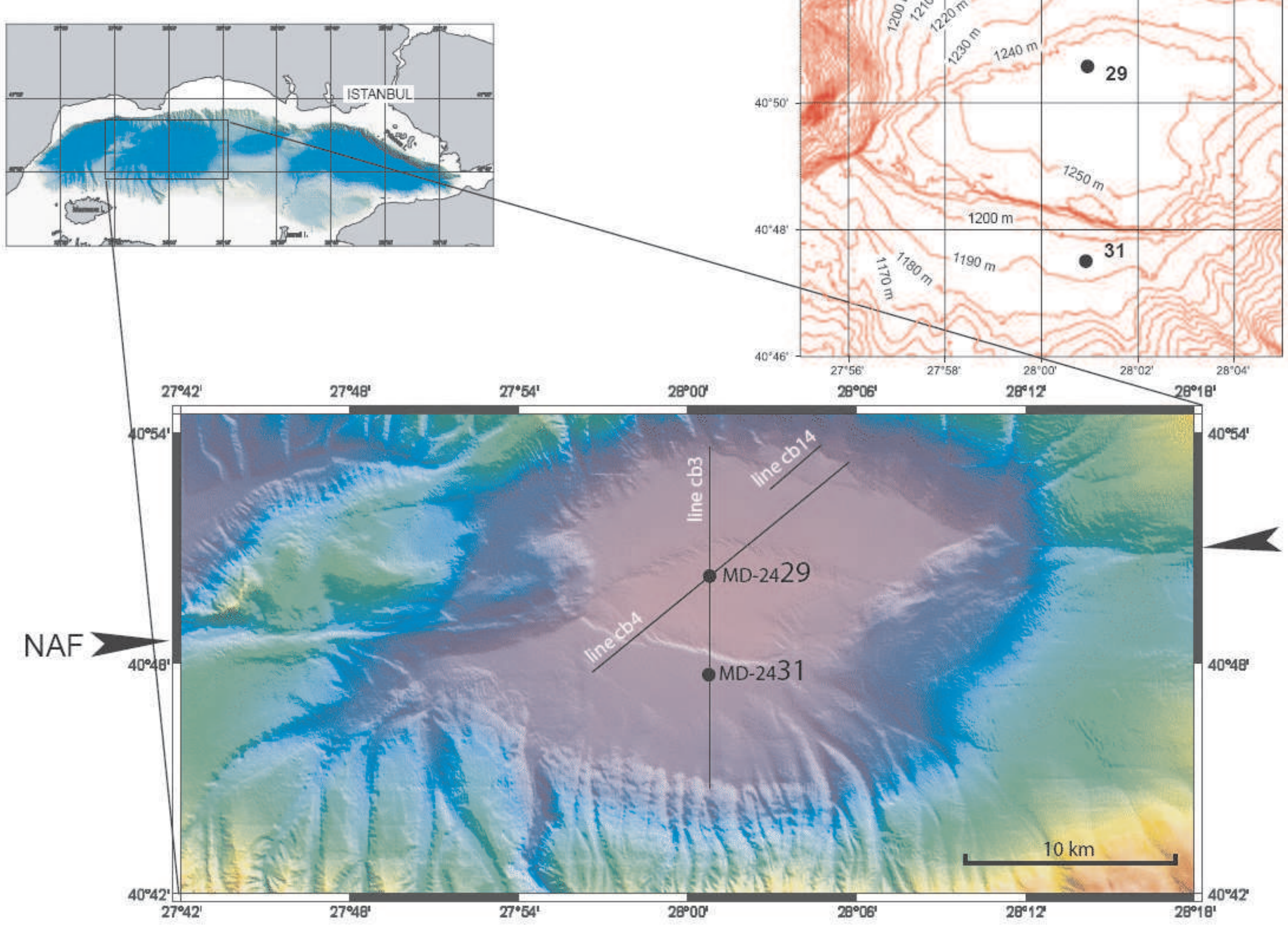




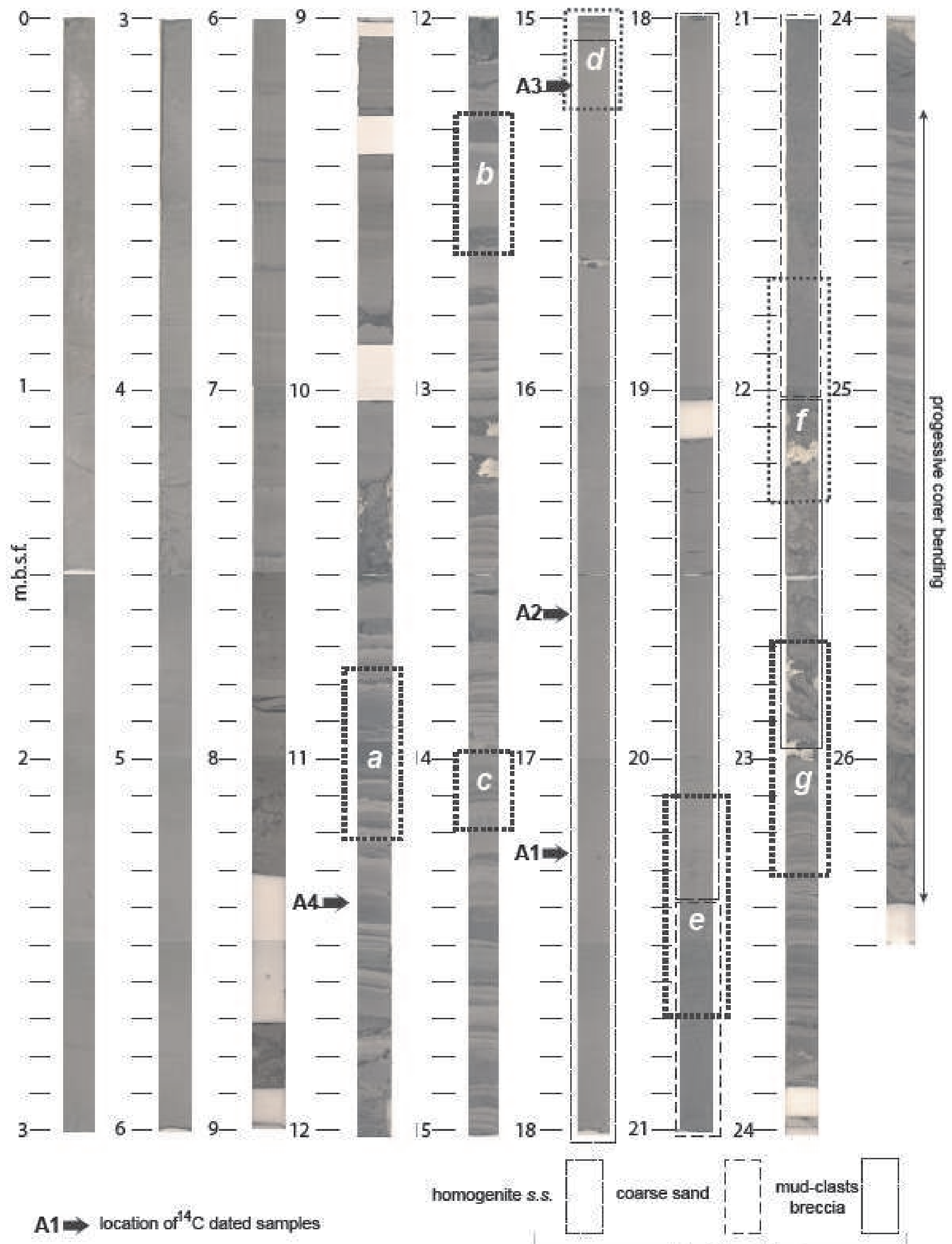




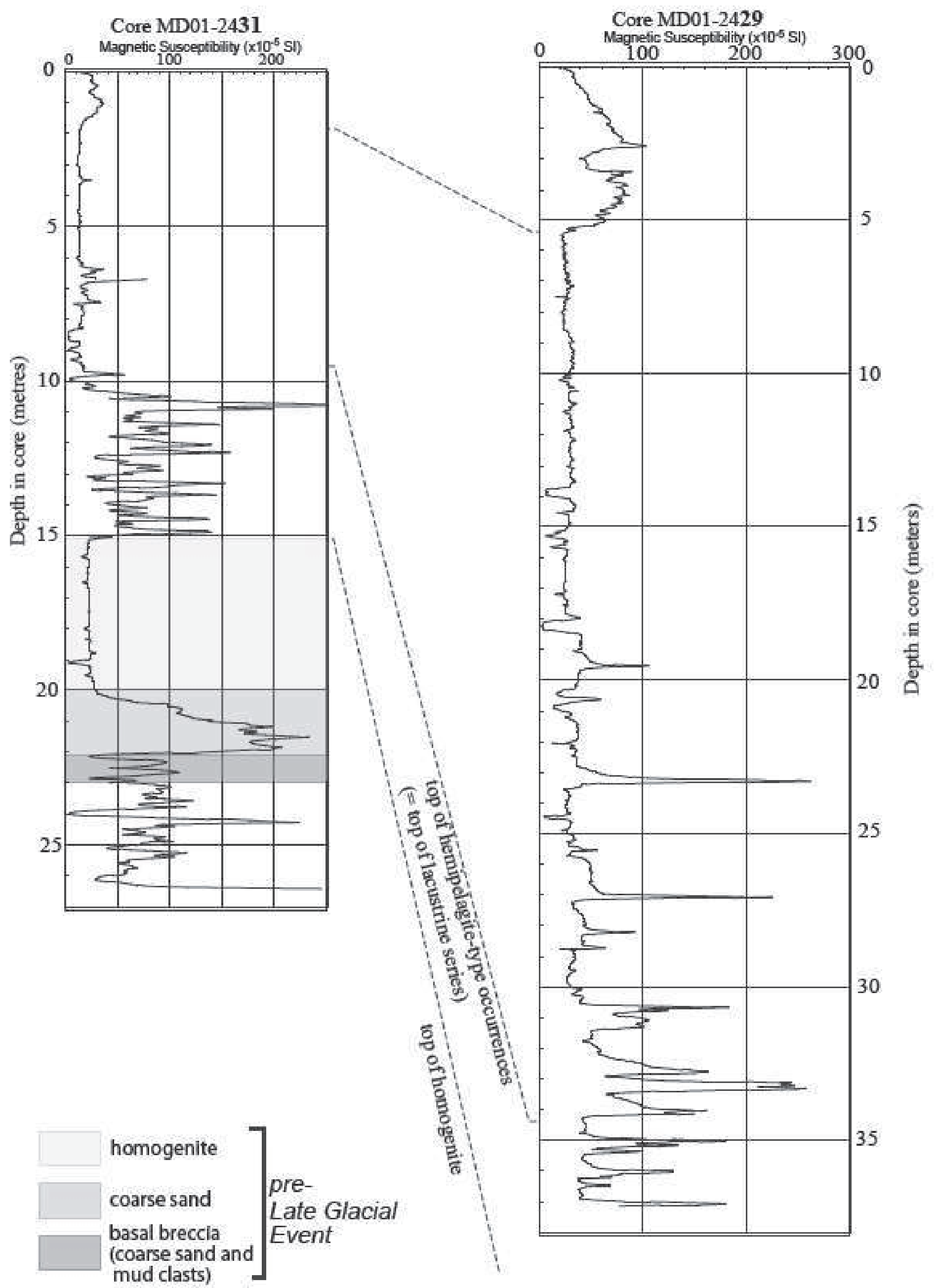

